\title{
Quartz Assemblage from the Early Mesolithic Helvetinhaudanpuro Settlement Site in Eastern Central Finland
}

\author{
T. Rostedt, A. Kriiska
}

For citation: Rostedt T., Kriiska A. Quartz Assemblage from the Early Mesolithic Helvetinhaudanpuro Settlement Site in Eastern Central Finland. Vestnik of Saint Petersburg University. History, 2019, vol. 64, issue 2, pp. 639-665. https://doi.org/10.21638/11701/spbu02.2019.213

Research of the occupation in the eastern shores of the Baltic Sea areas has been vivid over the last centuries and it has had different perspectives and thematic ranges. In this paper we present a overview of the history of Stone Age quartz research in Finland and general quartz working techniques and, above all, some results considering analysis of the quartz material from the Early Mesolithic settlement site of Helvetinhaudanpuro in Finland. It is surprising how little in archaeology has been paid attention to the changes in the variations of lithic technologies when groups of people moved from one area to another. If there were not any possibilities to use familiar stone materials as a technological starting point, adaptation to new materials was essential. In the lithic material of Helvetinhaudanpuro we detected characteristics connected to adaptation from flint to the local quartz. The shift in raw materials took place within a few hundred years and appears to coincide with the change in social networks related to the break in connections with previous habitation areas. The quartz techniques seen in Helvetinhaudanpuro are similar to those from other Finnish Mesolithic sites; bipolar technique dominates, but platform percussion has also been in use to some extent. There are some aspects in this material that are unusual, even special, and more compatible to flint than quartz technology: Helvetinhaudanpuro-type points, inserts and possible use of pressure flaking in some cases. These tool shapes and technical achievement indicate a deeper socio-cultural background and are a distinctive link between flint and quartz knapping technology.

Keywords: Early Mesolithic, Finland, quartz, lithic techniques.

Tapani Rostedt - MA, freelance archaeologist, Peltokatu, 18, 20540, Turku, Finland; tapaniro@hotmail.com

Тапани Ростедm - независимый исследователь (археология), Финляндия, 20540, Турку, ул. Пелтокату, 18; tapaniro@hotmail.com

Aivar Kriiska - PhD, Professor, Institute of History and Archaeology, University of Tartu, Jakobi 2, 51014, Tartu, Estonia; aivar.kriiska@ut.ee

Айвар Крийска - д-р философии (археология), проф. лабораторной археологии, Институт истории и археологии, Университет Тарту, Эстония, 51014, Тарту, ул. Якоби, 2; aivar.kriiska@ut.ee

This research was supported by the research project of the Estonian Research Council 'Estonia in Circum-Baltic space: archaeology of economic, social, and cultural processes' (IUT20-7) and "Natural selection and migrations in shaping human genetic diversity in East European Plain. An ancient DNA study" (PRG243).

Данное исследование выполнено при поддержке Научного совета Эстонии, проекты «Эстония в циркум-балтийском пространстве: археология экономических, социальных и культурных процессов» (IUT20-7) и «Естественный отбор и миграции в формировании генетического разнообразия населения Восточно-Европейской равнины. Исследование древнего ДНК» (PRG243)

(c) Санкт-Петербургский государственный университет, 2019 


\title{
Кварцевая индустрия из раннемезолитического поселения Хельветинхауданпуро на востоке центральной Финляндии
}

\author{
T. Ростедm, А. Крийска
}

Для цитирования: Rostedt T., Kriiska A. Quartz Assemblage from the Early Mesolithic Helvetinhaudanpuro Settlement Site in Eastern Central Finland // Вестник Санкт-Петербургского университета. История. 2019. Т. 64. Вып. 2. С. 639-665. https://doi.org/10.21638/11701/spbu02.2019.213

Изучение первичного заселения восточных берегов Балтийского моря на протяжении последних столетий осуществлялось весьма активно. Были исследованы различные аспекты и этапы этого процесса. В статье приведен обзор истории изучения вопросов использования кварца в каменном веке Финляндии, общих методов обработки этого материала, а также представлены результаты анализа кварцевого материала раннемезолитического поселения Хельветинхауданпуро в Финляндии. История изучения проблематики использования кварца показывает, как мало в археологии уделялось внимания вариациям каменных технологий при перемещении групп людей из одного района в другой. При невозможности использования известного каменного сырья и знакомой технологии возникала необходимость в приспособлении к новому материалу. В каменном материале Хельветинхауданпуро мы выделили характеристики, указывающие на адаптацию технологий обработки кремня к местному сырью - кварцу. Переход к другому виду сырья осуществлялся в течение нескольких сотен лет и, веротятно, совпал с социальными изменениями, обусловленными разрывом контактов с предыдущими районами обитания. Техники обработки кварца, наблюдаемые в Хельветинхауданпуро, очень похожи на техники других мезолитических стоянок Финляндии. Среди них доминировала биполярная, но в некоторой степени использовалась и площадочная техника. В находках на этой территории отмечаются уникальные особенности, более характерные для кремневых, чем для кварцевых технологий, среди них - острия типа хельветинхауданпуро и вкладыши, а в некоторых случаях, вероятно, использовалась отжимная техника расщепления. Эти формы орудий и технические достижения, возможно, имеют более глубокие социальные и культурные причины и являются отличительной чертой, связывающей технологии расщепления кремня и кварца.

Ключевые слова: ранний мезолит, Финляндия, кварц, техники обработки камня.

\section{Introduction}

The earliest inhabitants of Finland appear to have easily adopted quartz as a raw material for manufacturing small tools. Since Finland do not have natural sources of flint, it was necessary for the settlers to find a substitute for this material. It is possible that the fast transition to utilise quartz was also influenced by previous contacts with the material that had been used before arriving in Finland. However, the proportion of quartz in Early Mesolithic settlement sites within the "flint zone" remains extremely low. For instance, quartz makes up only $0.7 \%$ of the lithics found in the Early Mesolithic site of Pulli in Estonia ${ }^{1}$.

This early period of change in lithic raw materials is observable, among other things, in the characteristic features of the Finnish quartz percussion techniques.

Considering the abundance of quartz artefacts from Finnish Stone Age and Bronze Age settlement sites, it seems strange that during more than a hundred years of research,

${ }^{1}$ Jussila T., Kriiska A., Rostedt T. The Mesolithic Settlement in NE Savo, Finland and the earliest Settlement in the Eastern Baltic Sea // Acta Archaeologica. 2007. Vol. 78, iss. 2, fig. 12. 


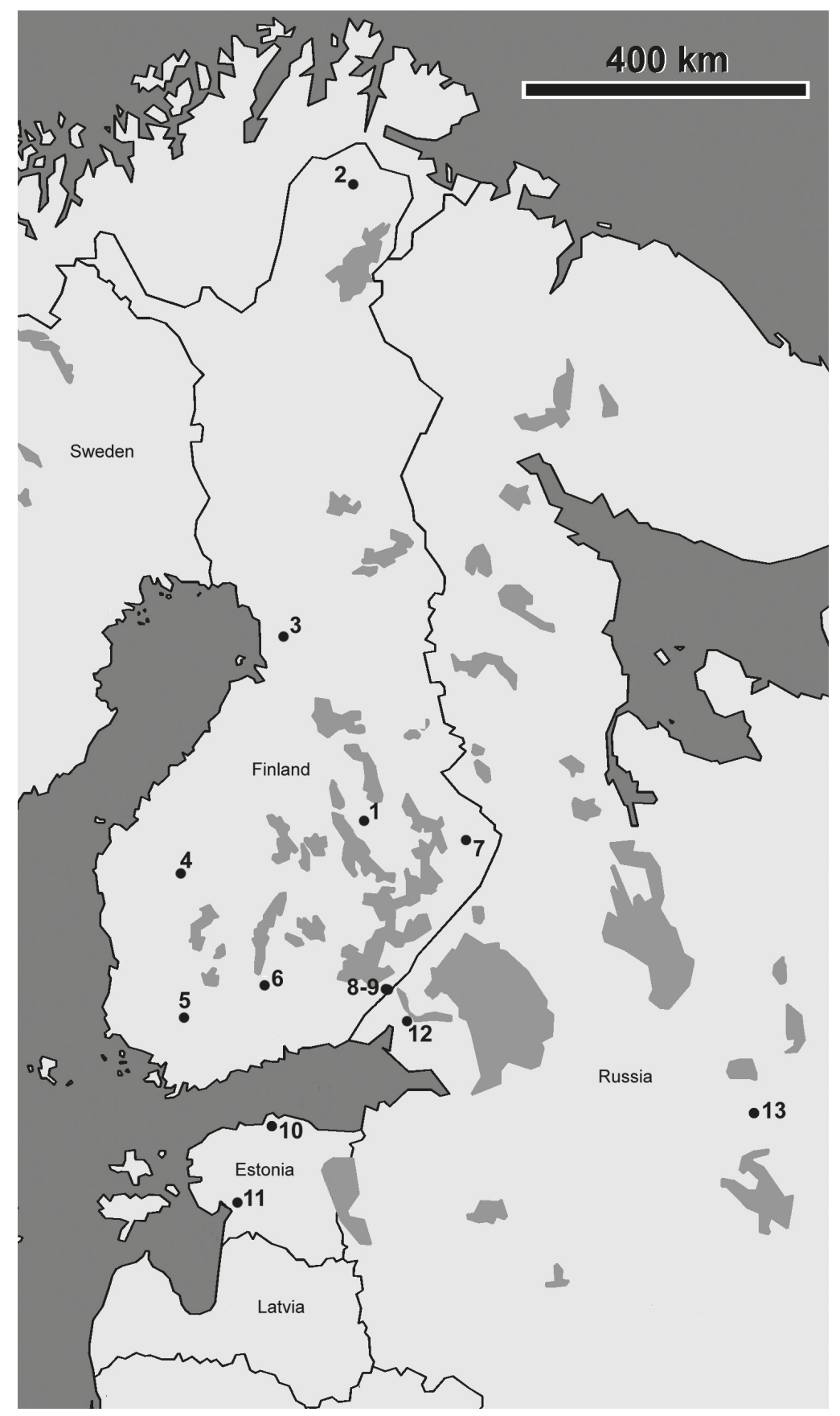

Fig. 1. Sites mentioned in the text. Finland:

1 - Juankoski Helvetinhaudanpuro; 2 - Utsjoki Sujala; 3 - Yli-Ii Kierikinsaari; 4 - Alavus Ojalankangas; 5 - Urjala Palomäki; 6 - Lahti Ristola; 7 - Eno Jokivarsi 1; 8-9 - Lappeenranta Saarenoja 2 and Muilamäki, Estonia; 10 - Kunda Lammasmägi; 11 - Pulli, Russia; 12 - Veshevo 2 and 13 - Lotova Gora (Map based on [Jussila et al., 2007, fig. 1] and Tapani Rostedt) 
only relatively little attention has been paid to this mineral. From the 2000 onward, there has been an increasing interest in the technological characteristics of quartz knapping. In Finland, the new pioneers of quartz technology include, first and foremost, Tuija Rankama and Jarmo Kankaanpää. They continue the inspection of quartz from where Ville Luho and Ari Siiriäinen decades ago concluded. Their persistent research and analysis of quartz technology awoke the field from a long slumber, and new articles on the topic are published by various researchers almost annually ${ }^{2}$.

For a long time, quartz was a relatively underappreciated lithic material. Experimental studies have shown that the fracture properties of quartz are not even close to those of flint and therefore flint knapping techniques cannot be directly applied to quartz ${ }^{3}$. The fracture properties of quartz, and especially its tendency to shatter when struck, no doubt create challenges for research, but we believe that general trends can still be observed. Formal percussion techniques have usually been the main subject in quartz technology studies. These rely on the assumption that mobility and the low availability of well-flaking lithics have caused simplification of earlier percussion techniques ${ }^{4}$. Generally, research on quartz knapping techniques has been rather moderate in the last decades and new interpretations regarding knapping traditions have not appeared.

This article sets three main aims: 1 ) to give an overview of the history of quartz research in Finland; 2) to discuss general techniques used when working with quartz, and above all 3) to present the results of analysis of the quartz material from the Early Mesolithic settlement site of Helvetinhaudanpuro in Juankoski. Notably, it is possible to observe some distinctive features in the quartz percussion technique in the Helvetinhaudanpuro material, a fact that might give a reason to look for similarities in other assemblages in the

${ }^{2}$ Rankama T. Ala-Jalve. Spatial, technological, and behavioral analyses of the lithic assemblage from a Stone Age Early Metal Age site in Utsjoki, Finnish Lapland // British Archaeological Reports, International Series. Vol.681. Oxford, 1997; Takala H. The Ristola Site in Lahti and the Earliest Postglacial Settlement of South Finland. Jyväskylä, 2003; Kankaanpää J. \& Rankama T. Early Mesolithic Pioneers in Northern Finnish Lappland // Pioneer Settlements and Colonization Processes in the Barents Region // Vuollerim Papers on Hunter-Gatherer Archaeology. Vol. 1 / ed. by H. Knutsson. Vuollerim 6000 År: Vuollerim, 2005. P. 109-161; Jussila T., Kriiska A., Rostedt T. The Mesolithic Settlement in NE Savo, Finland and the earliest Settlement in the Eastern Baltic Sea // Acta Archaeologica. 2007. Vol. 78, iss. 2. P. 143-162; Rankama T., Kankaanpää J. Eastern arrivals in post-glacial Lappland: The Sujala site 10000 cal BP // Antiquity. 2008. Vol. 82. P. 884-900; Tallavaara M., Manninen M. A., Hertell E. \& Rankama T. How flakes shatter. A critical evaluation of Quartz fracture analysis // Journal of Archaeological Science. 2010. Vol.37. P.2442-2448; Hertell E., Tallavaara M. High Mobility or Gift Exchange: early Mesolithic chipped lithics in Southern Finland // Mesolithic interfaces: Variability in lithic technologies in eastern Fennoscandia / ed. by T. Rankama. Saarijärvi, 2011. P. 11-41; Jussila T., Kriiska A., Rostedt T. Saarenoja 2 - An Early Mesolithic Site in South-Eastern Finland: Preliminary Results and Interpretations of Studies Conducted in 2000 and 2008-10 // Fennoscandia archaeological. 2012. Vol. XXIX. P. 3-27; Manninen M. A. Culture, Behavior and the 8200 cal BP Cold Event. Organisational Change and Culture-environmental Dynamics in Late Mesolithic Northern Fennoscandia. Vol.4. Helsinki. 2014; Manninen M.A., Knuttson K. Lithic raw material diversification as an adaptive strategy - Technology, mobility and site structure in Late Mesolithic northern mosts Europe // Journal of Athropological Archaeology. 2014. Vol.33. P. 84-98.

${ }^{3}$ Luho V. Die Askola-Kultur. Die frühmesolitische Steinzeit in Finnland. (Suomen Muinaismuistoyhdistyksen Aikakauskirja. Vol.57. Helsinki. 1956. P.116-117; Siiriäinen A. Problems of the East Fennoscandian Mesolithic. Finskt Museum 1977. Helsinki, 1981. P. 14-15; see also: Rankama T. Ala-Jalve. Spatial, technological, and behavioral analyses of the lithic assemblage from a Stone Age Early Metal Age site in Utsjoki, Finnish Lapland. (British Archaeological Reports, International Series. Vol. 681). Oxford, 1997.

${ }^{4}$ See e.g. Knutsson H., Knutsson K., Molin F., Zetterlund P. From flint to quartz: Organisation of lithic technology in relation to raw material availability during the pioneer process of Scandinavia // Quaternary International. 2016. Vol. 424. P.32-57. 
future. Based on a thorough analysis and comparative studies of the lithics from different settlement sites, it appears that the percussion techniques used by the pioneer settlers, who arrived in what is now modern-day Finland, initially incorporated 'memories' of previous stone-working techniques into quartz knapping. Later, the percussion techniques were simplified to an extent, but the function of tools remained the same for some time. Thus, the manufacturing technique was simplified due to the percussion properties of quartz, while simultaneously the tools became more multifunctional.

Previously, conducting long-term analysis was more complicated because the quartzes found in multi-period settlement sites did not necessarily represent only one period of occupation. Over the last decade the situation has changed for the better because more studies have been conducted on Early Mesolithic sites that were in use for a relatively short period of time. At the same time, reference material for specific time periods in Finland has increased, and the results are more accurate $\mathrm{e}^{5}$. The relatively short occupation period at Helvetinhaudanpuro adds credibility to the quartz assemblage from the site.

\section{History of quartz studies in Finland}

In the early days of lithic technological studies in Europe in the $19^{\text {th }}$ century, research was driven by general developments in archaeology: the birth of periodization, typology, and borrowing from the natural sciences. The creation of Palaeolithic periodization was of utmost importance: the evolution of lithic technology from fewer complexes to more complex types and to knapping techniques requiring the production of a core. The focus in lithic technology was on flint. Quartz was different, marginalised, and had almost no effect on the general study of lithic. It did not play a notable role even in areas such as Finland, where quartz was basically the only lithic raw material used for making small tools.

The fact that quartz was underappreciated in the early days of archaeology in Finland can be confirmed by the lack of systematic collection of the material during excavations. More attention to finding, collecting and studying quartz was paid from 1910 onward. Although Julius Ailio ${ }^{6}$ [1909] described quartz material to some extent in his dissertation, Sakari Pälsi is considered the forerunner of quartz studies in Finland ${ }^{7}$. He studied the

${ }^{5}$ Jussila T., Kriiska A., Rostedt T.: 1) Varhaismesoliittisesta asutuksesta Koillis-Savossa - alustavia tuloksia Juankosken Akonpohjan Helvetinhaudanpuron asuinpaikan kiviaineistosta // Arkeologia ja kulttuuri. Uutta kivikauden tutkimuksessa. Arkeologipäivät. 2005. Hamina, 2006. P. 50-61; 2) The mesolithic Settlement in NE Savo, Finland and the earliest Settlement in the Eastern Baltic Sea // Acta Archaeologica. 2007. Vol. 78, iss. 2. P. 143-162; 3) Saarenoja 2 - An Early Mesolithic Site in South-Eastern Finland: Preliminary Results and Interpretations of Studies Conducted in 2000 and 2008-10 // Fennoscandia archaeological. 2012. Vol. XXIX. P. 3-27; Kankaanpää J., Rankama T. Spatial Patterns of the Early Mesolithic Sujala Site. Utsjoki, Finnish Lappland // Mesolithic interfaces: Variability in lithic technologies in eastern Fennoscandia. Saarijärvi, 2011. P. 42-63; Rankama T., Kankaanpää J. Fast or slow pioneers? A view from Northern Lappland. Lateglacial and Postglacial Pioneers in Northern Europe // British Archaeological Reports, International Series. Vol. 2599. Oxford, 2014. P. 147-160; Kriiska A., Rostedt T., Jussila T. The Development of Early Mesolithic Social Networks During the Settlement of Virgin Lands in the Eastern Baltic Sea Region- Interpreted through Comparison of Two Sites in Finland // Comparative Perspectives on Past Colonisation, Maritime Interaction and Cultural Integration (New Directions in Anthropological Archaeology) / eds L. Melheim, H. Glørstad and Z. Glørstad. South Yorkshire, 2016. P. 19-40.

${ }^{6}$ Ailio J. Die Steinzeitliche Wohnplatzfunde in Finland I-II. Helsingfors, Kommission bei der Akademischen Buchhandlung, 1909.

${ }^{7}$ Luho V. Die Askola-Kultur. Die frühmesolitische Steinzeit in Finnland. (Suomen Muinaismuistoyhdistyksen Aikakauskirja. Vol.57). Helsinki, 1956. P. 16; Luho V. Die Suomusjärvi-Kultur. Die mittel- und 
shapes and retouches of the quartz assemblage from the Palomäki Stone Age settlement site in Urjala ${ }^{8}$. Aarne Europaeus (Äyräpää) ${ }^{9}$ published similar descriptions of quartz tools from the assemblage of the Stone Age settlement site of Ojalankangas in Alavus. He recognised that quartz had been an important raw material, at least in Western and Northern Finland.

Quartz did not receive much recognition again after the works of Pälsi and Europaeus until the studies by Ville Luho in the $1940 \mathrm{~s}^{10}$. Luho researched the earliest occupation of Finland and quartz technology, comparing the physical characteristics of the latter to those seen in flint technology. He assumed that the similarity in forms of quartz tools with flint tools was a sufficient reason to adapt the Central European Paleolithic typology to Finnish material. In his opinion, quartz tools were made by applying flint knapping techniques. Therefore, artefact types correspond and are comparable to those made from flint. According to Luho ${ }^{11}$, the differences in quartz technology concerned mainly the low quality of retouched blades and unpredictability of the material to fragmentation. Based on differences in quartz working techniques, he divided the Finnish Mesolithic into the Askola culture which was followed by the Suomusjärvi culture. He emphasized the large size of blades and blade cores found in the Askola culture, which prompted him to differentiate between the Askola and Suomusjärvi cultures ${ }^{12}$ on the basis of this old technological trait. Luho considered the quartz technology of the Neolithic Comb Ware culture a continuation of the Suomusjärvi tradition, without any major changes in technology or population ${ }^{13}$.

Luho's method of analysing quartz technology by comparing it directly to flint technology was later criticised. In his Master's thesis, Ari Siiriäinen ${ }^{14}$ studied the quartz assemblage from the Neolithic Asbestos Ceramic culture Yli-Ii settlement site. His intention was to find taxonomic differences in the material from the site dating to ca. 2000-1500 BC. In his work, Siiriäinen stressed how the fracture properties of quartz differ from those of flint. Since Luho had failed to do this, Siiriäinen considered his typology erroneous ${ }^{15}$. According to Siiriäinen, the uncritical application of typological terms derived from flint technology to characterize quartzes inevitably leads to incorrect conclusions. He believed

spätmesolitische zeit in Finnland // Suomen Muinaismuistoyhdistyksen Aikakauskirja. Vol.66. Helsinki, 1967. P. 10.

8 Pälsi S. Palomäen kivikautinen asuinpaikka Urjalassa // Suomen Museo 1913. Helsinki, 1913. P. 75-76.

9 Europaeus A. Ojalankankaan kivikauden löytöpaikka Alavudella // Suomen Museo 1916. Helsinki, 1919. P. 73-82; see also: Luho. 1956. P.16-17.

10 Ibid. P. 17.

11 Luho V. Die Askola-Kultur. Die frühmesolitische Steinzeit in Finnland // Suomen Muinaismuistoyhdistyksen Aikakauskirja. Vol. 57). Helsinki, 1956. P. 18; Luho V. Die Suomusjärvi-Kultur. Die mittel- und spätmesolitische zeit in Finnland. (Suomen Muinaismuistoyhdistyksen Aikakauskirja. Vol.66). Helsinki, 1967. P. 120.

${ }^{12}$ Luho V. Die Askola-Kultur. Die frühmesolitische Steinzeit in Finnland // Suomen Muinaismuistoyhdistyksen Aikakauskirja. Vol.57. Helsinki, 1956. P.116-117; Luho V. Die Suomusjärvi-Kultur. Die mittel- und spätmesolitische zeit in Finnland // Suomen Muinaismuistoyhdistyksen Aikakauskirja. Vol.66. Helsinki. 1967. P. 24.

${ }^{13}$ Luho V. Die Suomusjärvi-Kultur. Die mittel- und spätmesolitische zeit in Finnland // Suomen Muinaismuistoyhdistyksen Aikakauskirja. Vol. 66. Helsinki, 1967. P. 120.

14 Siiriäinen A. Yli-Iin Kierikin Asbestikeraamisen asuinpaikan kvartsiesineet. Lähdekriittinen tutkimus. Unpublished Master's thesis. University of Helsinki. Helsinki, 1968.

15 Siiriäinen A. Problems of the East Fennoscandian Mesolithic // Finskt Museum 1977. Helsinki, 1981. P. 6-14. 
that quartz and flint assemblages are not comparable in general because the introduction of quartz as a raw material caused the adaptation of new techniques which differed greatly from previous ones ${ }^{16}$. Based on quartz technology, Siiriäinen attributed the earliest occupation in Finland to the Suomusjärvi cultural area, which, in his opinion, uniformly influenced both Finland and neighbouring areas in the East during the Mesolithic period ${ }^{17}$.

The favourable strategies of prehistoric people related to lithic raw materials did not gain much international attention until the $1980 \mathrm{~s}^{18}$. Although research on the effect of properties of raw materials became particularly common in technological studies in North America, examination of quartz in Finland was world-class too at the time. In 1977, Ari Siiriäinen published an article in the journal Finskt Museum, in which he demonstrated how the quality and availability of raw materials used for crafting tools affected the overall composition of the archaeological assemblage in the River Rockshelter settlement site in Kenya (Eastern Africa). Siiriäinen did not, however, generalize his results but considered them as a starting point and encouraged further research into the connection between the properties of raw materials and the composition of the material culture in different areas and time periods. The availability and quality of raw materials is generally considered important, if not crucial, in lithic studies, and therefore this issue is still relevant and important.

Quartz was also explored thereupon by other archaeologists. Heikki Matiskainen dealt with quartz to some degree when studying the Suomusjärvi culture and material ${ }^{19}$. Hans-Peter Schulz ${ }^{20}$, on the other hand, studied Mesolithic quartz technologies in more detail. In his opinion, primary production was quite uniform. A hard or soft hammer was used on pieces of vein quartz, the bipolar technique was applied to a hard surface, and the platform percussion technique - on a striking platform. Pure platform technique was

16 Ibid. P. 14-15; Knutsson K. Garaselet-Lappviken-Rastklippan. Introduktion till en diskurssion om Norrlands Äldsta Bebyggelse // Tor. 1993. Vol.25. P. 12.

17 Siiriäinen A. Problems of the East Fennoscandian Mesolithic // Finskt Museum 1977. Helsinki, 1981. P. 18; Pankrušev G. A. Karjalan mesoliittinen ja neoliittinen kausi. Mesoliittinen kausi. Helsinki / eds P. Maaranen, M. Lavento, 1994. Vol. 1. P.67.

18 Bleed P. The Optimal Design of Hunting Weapons: Maintainability or Reliability // American Antiquity. 1986. Vol.51, iss.4; Bamforth D. B. Technological efficiency and tool curation // American Antiquity. 1986. Vol.51, iss. 1. P.38-50; Parry W. J., Kelly R. L. Expedient Core Technology and Sedentism. The Organization of Core Technology / eds J.K. Johnson, C. A. Morrow. Boulder, 1987. P. 285-304; Gero J.M. Assessing social information in material objects: how well do lithics measure up? // Time, energy and stone tools / ed. by R. Torrence. Cambridge, 1989. P.92-105; Hayden B. Practical and Prestige Technologies: The Evolution of Material Systems // Journal of Archaeological Method and Theory. 1998. Vol. 5, iss. 1. P. 1-55; Nelson M. C. The Study of Technological Organization // Archaeological Method and Theory. Vol.3, iss. 1. 1991. P. 57-100; Andrefsky W. Jr. Raw-material availability and the organization of technology // American Antiquity. 1994. Vol.59, iss. 1. P.21-34; Kuhn S. L. Mousterian lithic technology. Princeton, 1995; Brantingham P. J. et al. Raw Material Quality and Prepared Core Technologies in Northeast Asia // Journal of Archaeological Science. 2000. Vol.27. P. 255-271.

19 Matiskainen H.: 1) Beiträge zur Kentnisse der mesolitischen Schrägschneidepfeile und Mikrolithen aus Quarz. Studia praehistorica Fennica C F Meinander septuagenario dedicata // Iskos. Vol. 6. 1986. P.7798; 2) The Palaeoenvironment of Askola, Southern Finland. Mesolithic Settlement and Subsistence 100006000 b.p. // Iskos. 1989. Vol. 8.97 p.

${ }^{20}$ Schulz H.-P.: 1) On the Mesolithic Quarz Industry in Finland. Fenno-Ugri et Slavi. Papers presented by the participants in the Finnish-Soviet Archaeological Symposium 'Studies in the Material Culture of the Peoples of eastern and Northern Europe' 10-16 May 1988 in the National Museum of Finland // Iskos. Vol.9. 1988. P.7-23; 2) Pioneerit pohjoisessa. Suomen varhaismesoliittinen asutus arkeologisen aineiston valossa // Suomen Museo 1996. Helsinki, 1996. P.5-45. 
used, too. Schulz has also found evidence for bipolar blade percussion. According to him, Mesolithic quartz technology involves features from flint knapping technology. Although there are differences in the initial production phases of quartz and flint technologies, there are also similarities. Techniques used to shape the tools after initial reduction resemble those used for working flint, and therefore applying terminology from flint knapping is justified. Nevertheless, typology should still be based primarily on knapping technology and not just on appearance ${ }^{21}$.

When considering technology as part of a complex interdependent system, we are able to refer to stone tools to answer broader questions regarding production and use of artefacts. According to Margaret Nelson ${ }^{22}$, the most important result of the study of technological systems is the focus on the variables that influence the technology. In this way, the attention is shifted from the shape, production techniques or use of lithics, or from the picture these can produce of the activities occurring at the settlement site to the variables that cause change. The main objective of the study of technological systems has been to discover how changes in technology reflect broader changes in human behaviour ${ }^{23}$.

Inspired by the study of technological systems, recent research in Finnish lithic technology also deals with essential questions regarding stone working, artefact use and locating activity at settlement sites ${ }^{24}$.

\section{Quartz working techniques}

Knapping techniques are skills and capabilities mastered and used by a specific person. In archaeological lithic technological studies, technology usually refers to stone working customs. Lithic technological studies are often determined by research approaches; theoretical and philosophical principles, sometimes referred to as generalisations ${ }^{25}$.

Techniques and lithic raw material are interdependent because the characteristics of rocks influence their use and behaviour when being worked ${ }^{26}{ }^{26}$. The crystal structure

${ }^{21}$ Ibid. P.18; Callahan E. et al. Kulturhistoriska kommentarer till det säregna sönderfallet vid bearbetning av kvarts // Tor. 1992. Vol.24. P. 32.

22 Nelson M. C. The Study of Technological Organization // Archaeological Method and Theory. 1991. Vol. 3, iss. 1. P. 57-100.

${ }^{23}$ Kelly R. L. The three sides of a biface // American Antiquity. 1988. Vol. 53. P.717-734.

${ }^{24}$ Räihälä O. Suomussalmen Salonsaari kivikautinen leiripaikka Kiantajärven rannalla // Kirjoitelmia arkeologian alalta. Kentältä poimittua 4. Museoviraston arkeologian osaston julkaisuja. Vol. 7. Helsinki, 1997. P. 5-23; Rankama T. Ala-Jalve. Spatial, technological, and behavioral analyses of the lithic assemblage from a Stone Age Early Metal Age site in Utsjoki, Finnish Lapland // British Archaeological Reports, International Series. Vol.681. Oxford, 1997; Rankama T. Analyses of the Quartz Assemblages of Houses 34 and 35 at Kauvonkangas in Tervola // Huts and Houses. Stone Age and Early Metal Age Buildings in Finland / Ed. by H. Ranta. Helsinki, 2002. P.79-108; Manninen M. A. Chaîne opératoire-analyysi ja kvartsi. Esimerkkinä kvartsiniskentäpaikka Utsjoki Leakšagoađejohka 3, Master's thesis. E-thesis, University of Helsinki, 2004. Available: http://urn.fi/URN:NBN:file 200319462003 (accessed: 18.04.2018); Manninen M. A., Tallavaara M., Hertell E. Subneolithic bifaces and flint assemblages in Finland. Outlining the history of research and future questions. Uniting Sea. Stone Age societies in the Baltic Sea region // Papers in Archaeology. Vol. 33. Uppsala, 2003. P. 161-179; Hertell E., Manninen M.A. Rävåsens kvartsmaterial // Finskt Museum 2002. Helsinki, 2005. P. 84-100; Pesonen P., Tallavaara M. Esihistoriallinen leiripaikka Lohjan Hossanmäellä- kvartseja ja yllättäviä ajoituksia // Suomen Museo 2005. Helsinki, 2006. P. 5-26.

25 Trigger B. G. A History of Archaeological Thought. Cambridge, 1989.

${ }^{26}$ Rajala U. Kvartsiteknologian tutkiminen ja luokittelu Turun Niuskalan Kotirinteen kiukaiskeraamisen asuinpaikan vuosien 1983 ja 1984 kvartsilöydöt. Unpublished Master’s thesis, University of Turku. Turku, 1995. 
of rock affects its fracture properties and ability to flake; in microcrystalline rocks the crystals cause the rock to fragment when external constructive forces surpass the resolution of the crystals. Different rocks have different crystal structures, which influence the controllability during knapping. Quartz and other minerals in the same group are generally comprised of silicone dioxide $\mathrm{SiO}_{2}{ }^{27}$. In addition to common quartz and its colour variants, the quartz group includes silicone dioxides that are stable in room temperature, such as flint, calchedony, agate, jasper and opal.

Quartz and other lithic raw materials utilized in prehistory occur naturally in bedrock as veins or nodules. The lithic raw material most probably would have been collected either by digging or by taking advantage of vein quartz deposits. To determine the collection method used, one can analyse the quality of quartz, and look for the presence of an erosion surface, a sign of moraine quartz.

Quartz is hard but brittle. The relative hardness of quartz is 7 on the Mohs' 10-point hardness scale. Due to its structure, quartz behaves differently from flint when worked; a flint flake will usually remain intact, whereas a quartz flake will shatter into many fragments. An experimental study conducted by Swedish researchers in the 1980s and 1990s found that fragmentation is a not as random as was previously thought, but follows certain rules of fracture mechanics ${ }^{28}$. In addition, the internal flaws of quartz influence its working properties just as its brittleness causes fragmentation. These internal flaws cause fragmentation along pre-existing planes of fracture lines, making it difficult to predict and control the shape and size of flakes ${ }^{29}$. The problem is not nearly as severe with flint and therefore predictability with flint is much better. It seems, however, that there is some predictability in quartz knapping when reduction sequences are not conducted too rapidly, and the material is checked periodically during different reduction sequences.

Distinguishing knapping methods and percussion techniques is intriguing because different techniques are suitable for producing different types of tools. By using bifacial reduction, it is possible to produce flakes suitable for use as blanks for tools, and to work retouched tools. Platform percussion is suited for making both blanks and shaping and sharpening tools such as scrapers. With bipolar percussion, however, it is possible to produce mostly flake blanks used to manufacture other tools. In North American scholarship, this technique is considered especially well-suited for working small-sized pieces of raw material. Due to this, bipolar percussion is considered to have been the method employed when there was a need to utilize raw material as economically as possible ${ }^{30}$.

In principal quartz knapping, there are two basic techniques - platform percussion and bipolar percussion. Bifacial reduction is rare in quartz knapping and will therefore not be described in detail here. In platform percussion, the core is usually an artefact with one

27 Eskola P. Kidetieteen, mineralogian ja geologian alkeet. Porvoo, 1957. P. 65.

28 Callahan E., Forsberg L., Knutsson K., Lindgren C. Frakturbilder. Kulturhistoriska kommentarer till det säregna sönderfallet vid bearbetning av kvarts // Tor. 1992. Vol.24. P. 27-63; Siiriäinen A. Quartz, Chert and Obsidian. A Comparison of Raw Materials in a Late Stone Age Aggregate in Kenya // Finskt Museum 1974. Helsinki, 1977. P. 15-16.

29 Siiriäinen A. Quartz, Chert and Obsidian. A Comparison of Raw Materials in a Late Stone Age Aggregate in Kenya // Finskt Museum 1974. Helsinki, 1977. P. 15-16.

30 Andrefsky W. Jr. Lithics. Macroscopic approaches to analysis. (Cambridge Manuals in Archaeology). 1998. P. 119-120, 149; Tallavaara M. Vihiä teknologisista strategioista. Tutkimus Rääkkylän Vihin kampakeraamisen ajan asuinpaikan piikivi- ja kvartsiaineistoista. Master's thesis. E-thesis, University of Helsinki, 2007. P. 24. Available: http://urn.fi/URN:NBN:fi-fe20072153 (accessed: 15.03.2018). 
or more flat surfaces, for which the force needed for flake detachment is adapted. Techniques used were percussion, striking or pressure ${ }^{31}$. In platform percussion, the core is held in one hand, supported by the thighs, for example, and flakes or blades are detached using a percussion stone or some other percussion tool. The strikes are directed diagonally towards the edge of the platform, causing the detachment of a flake that has retained a piece of the platform. It is typical that flakes produced with platform percussion do not have sharp, but rather upright angles between the surface of the platform and the dorsal side of the flake. Other distinctive features of platform percussion are bulbs of percussion, eraillure scars and arrises ${ }^{32}$.

In platform percussion, an anvil can be used as a support. In this case, the quartz is placed on an anvil. When striking the core, the pressure of percussion is directed towards the edge of the platform and not directly from above to the anvil. The technique is still considered platform percussion as long as the aforementioned characteristics can be detected. Platform-on-anvil reduction is sometimes considered a fusion between platform percussion and bipolar percussion. If the raw material has been reduced to a very small size by later reduction sequences, then bipolar percussion techniques can often be applied in addition ${ }^{33}$. The bipolar blade production mentioned by Schulz can technically be placed within this category ${ }^{34}$.

The anvil is also used as a support in bipolar percussion. In this case, the quartz core is placed on an anvil and struck directly from above, causing the percussion force to move towards the anvil. The percussion force enters the core from two sides: from the direction of the percussion and from the anvil. With hard blows the stress in quartz is broken, causing the flaking to follow the cracks in the material. As a result of bipolar percussion, flakes detach from both ends of the core. One of the main characteristics of the technique is the presence of radiating fissures on the both ends of the core. Contrary to platform percussion, the bipolar technique does not generally have a proper remnant of a platform or a defined bulb of percussion, but the eraillure scars in the core and flakes can be well defined. Flakes created using the bipolar technique can be thinner and therefore more practical in certain circumstances than those created with the platform percussion technique ${ }^{35}$.

31 Tallavaara M. Vihiä teknologisista strategioista. Tutkimus Rääkkylän Vihin kampakeraamisen ajan asuinpaikan piikivi- ja kvartsiaineistoista. Master's thesis. E-thesis, University of Helsinki, 2007. P. 73. Available: http://urn.fi/URN:NBN:fi-fe20072153 (accessed: 15.03.2018).

32 Crabtree D.E. An introduction to the technology of stone tools. (Occasional papers of the museum, number 28). Pocatello (Idaho), 1972. P.11; Knutsson K. Making and using stone tools. The analysis of the lithic assemblages from the Middle Neolithic sites with flint in Västerbotten, northern Sweden. (Aun. Vol. 11). 1988. P.37.

33 Knutsson K. Making and using stone tools. The analysis of the lithic assemblages from the Middle Neolithic sites with flint in Västerbotten, northern Sweden. (Aun. Vol.11). 1988. P. 148-149; Olofsson A. Early Colonization of Northern Norrland: Technology, Chronology, and Culture. Pioneer Settlement in the Mesolithic of Northern Sweden. (Archaeology and Environment. Vol. 16). Umeå, 2003. P. 5

34 Schulz H.-P. On the Mesolithic Quarz Industry in Finland // Fenno-Ugri et Slavi. Papers presented by the participants in the Finnish-Soviet Archaeological Symposium "Studies in the Material Culture of the Peoples of eastern and Northern Europe" 10-16 May 1988 in the National Museum of Finland. (Iskos. Vol.9). P.7-23; Olofsson A. Early Colonization of Northern Norrland: Technology, Chronology, and Culture. Pioneer Settlement in the Mesolithic of Northern Sweden. (Archaeology and Environment. Vol. 16). Umeå, 2003. P. 71-72.

${ }_{35}$ Crabtree D. E. An introduction to the technology of stone tools // Occasional papers of the museum, number 28. Pocatello (Idaho), 1972. P. 10-11; Callahan E. An evaluation of the lithic technology in middle Sweden during the Mesolithic and Neolithic. (Aun. Vol.8). Uppsala, 1987. P.61; Rankama T. Ala-Jalve. 
To guarantee better controllability during knapping and flake detachment, indirect percussion can be applied. When using this method, a punch made from a bone, stone or dense wood is placed on a desired location on the platform and struck with a hammerstone. Tools fashioned in this way are finer than those manufactured with the basic technique because the naturally occurring cracks in quartz can be utilized more efficiently. The resulting flakes are smaller and more consistent than those made with the basic technique ${ }^{36}$.

If the core is not supported well during knapping, it eventually begins to bend. If force is applied in this situation, it will not go right through the core as intended. As a result, flakes are shorter than planned. If the item is supported securely, it will be easier to take advantage of materials fracture properties ${ }^{37}$. An anvil and stones with defined edges can be used as supports to stabilise cores during flaking ${ }^{38}$.

The pressure technique can also be applied as an aid when shaping and strengthening blades. For this, a bone, antler or wooden tool is used to press out small pieces from the edge. The force to be used is determined by the size of the pieces to be removed. In situations requiring more force, the shoulder or chest can be used along with long tools. Flakes resulting from the use of pressure technique are often very consistent and thin compared to those made with the basic technique.

\section{Helvetinhaudanpuro settlement site}

The Helvetinhaudanpuro site is located on top of a high and gently sloping fossilized 7-10 $\mathrm{m}$ wide ancient shore escarpment ${ }^{39}$. According to the shore displacement chronology of Lake Saimaa, the water level was near the top edge of the escarpment (112 m a.s.1.) about $8500 \mathrm{cal} \mathrm{BC}$ and at the foot of the escarpment (108 m a. s. 1.) about $8400 \mathrm{cal} \mathrm{BC}$ during the Ancylus Lake Phase of the Baltic Sea basin. At this location, the highest shoreline of ancient Lake Saimaa lies some $160 \mathrm{~m}$ further down the gentle slope at an elevation of $99 \mathrm{~m}$ a.s.l., where the water level stood c. $4800-4000 \mathrm{cal} \mathrm{BC}$. Today, the nearest body of water is Lake Akonjärvi, part of the present Saimaa Lake system located $1.5 \mathrm{~km}$ west of the site at an elevation of $82 \mathrm{~m}$ a.s.l. The water of this lake has been at the present level since the beginning of the ancient Lake Saimaa transgression phase, soon after the isolation of the Saimaa lake complex from the early Litorina Sea c. $7000 \mathrm{cal} \mathrm{BC}^{40}$.

Spatial, technological, and behavioral analyses of the lithic assemblage from a Stone Age Early Metal Age site in Utsjoki, Finnish Lapland // British Archaeological Reports, International Series. Oxford, 1997. Vol.681. P.73; Tallavaara M. Vihiä teknologisista strategioista. Tutkimus Rääkkylän Vihin kampakeraamisen ajan asuinpaikan piikivi- ja kvartsiaineistoista. Master's thesis. E-thesis, University of Helsinki, 2007. P.43-44. Available: http://urn.fi/URN:NBN:fi-fe20072153 (accessed: 15.03.2018).

36 Crabtree D. E. An introduction to the technology of stone tools // Occasional papers of the museum. Number 28. Pocatello (Idaho), 1972. P. 12-13.

37 Whittaker J. C. Flintknapping. Making and understanding stone tools. Austin, 1994. P. 151.

38 Pelegrin J. Blade-Making Techniques from the Old World: Insights and Applications to Mesoamerican Obsidian Lithic Technology // Mesoamerican Lithic Technology: Experimentation and interpretation / Ed. by K. Hirth. Salt Lake City, 2003. P. 65

39 Jussila T., Kriiska A., Rostedt T. The mesolithic Settlement in NE Savo, Finland and the earliest Settlement in the Eastern Baltic Sea // Acta Archaeologica. 2007. Vol. 78, iss. 2. P. 143-162.

40 Saarnisto M. The late Weichselian and Flandrian History of the Saimaa Lake Complex // Commentationes physico-mathematicae. Vol.37. 1970. P. 3-7; ${ }^{14} \mathrm{C}$-dates calibrated // Jussila T. Saimaan kalliomaalausten ajoitus rannansiirtymiskronologian perusteella. Saimaan ja Päijänteen alueen kalliomaalausten si- 


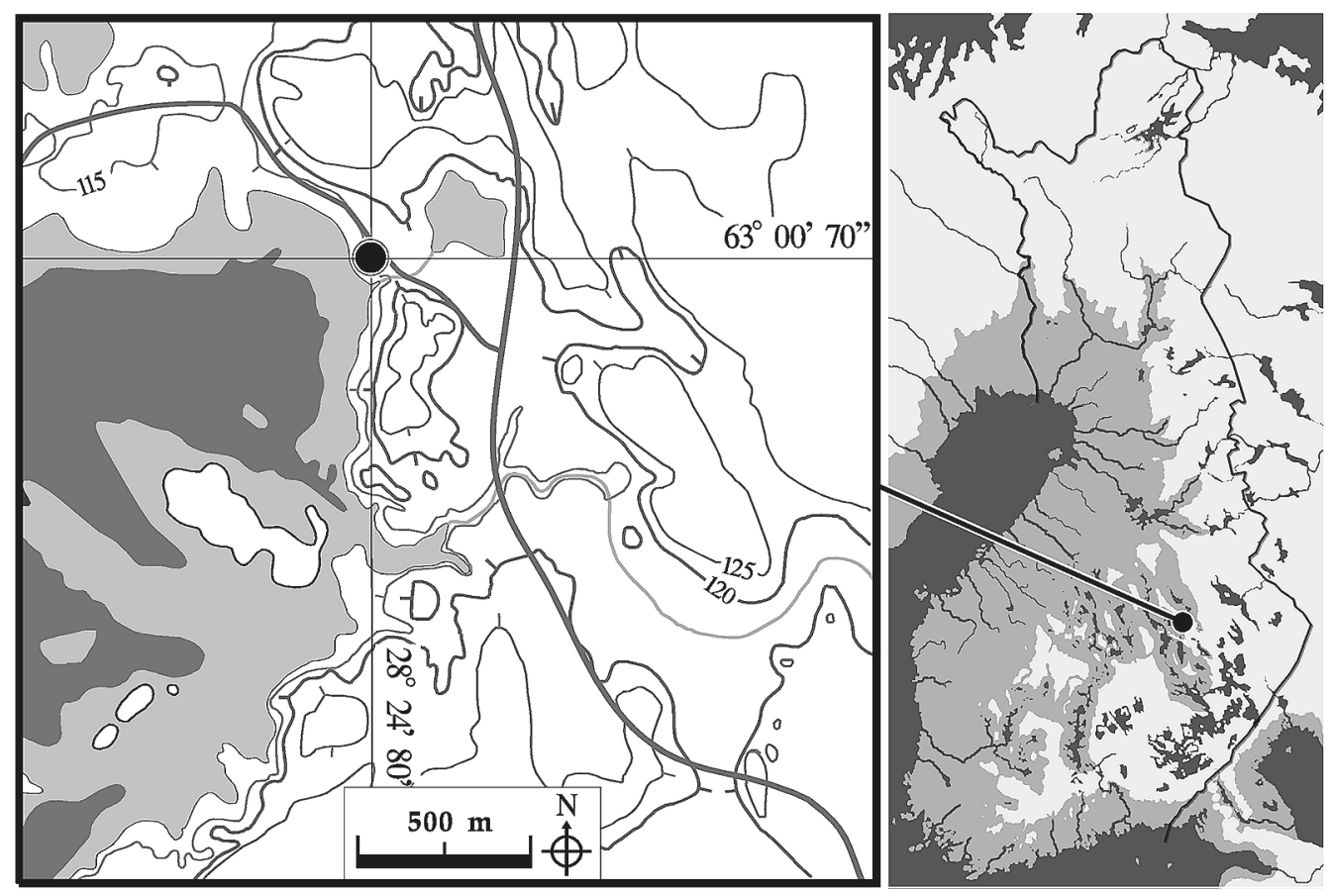

Fig. 2. Location of Helvetinhaudanpuro site. Light grey indicates water level $8500 \mathrm{cal} \mathrm{BC}$, darker grey is present water level (map by [Jussila et al., 2007, fig. 2])

The site was situated along the Ancylus Lake opening to the southwest and was located on the northwestern side of a small river mouth at the base of a 600-1000 m wide bay sheltered by an archipelago. The site lies on a c. $25 \mathrm{~m}$ wide terrace between the ancient shore escarpment and a gently rising slope (Figs 2 and 3). The terrain rises in all directions except southwest and west as seen from the site. When the site was occupied, the water directly in front of it was moderately deep, but on the north-western side the shore became shallow.

The site lies on the edge of a glacifluvial esker where the deposited sand of the esker turns into till. The soil at the site is quite loose equigranular sand; at the root of the escarpment it turns into fine sand and further downhill to silty till. To the north of the site the esker expands into a glacifluvial delta with kettle holes. 200 meters northeast of the site is a kettle hole c. $200 \mathrm{~m}$ in diameter with a maximum depth of some five to six meters. In this depression, there was a pond that is now almost completely paludified. From this pond, an ancient riverbed with steep banks runs directly to the south-eastern edge of the site where a small but fairly deep river discharged into the Ancylus Lake. On the opposite side of the ancient riverbed the terrain becomes somewhat more uneven, and on the upper slopes there are also outcrops of bedrock. Farther towards the southeast the soil is sandy till with a stony topsoil that has so far yielded no traces of prehistoric activities. Northwest of the site the topsoil becomes stonier, while the site area and its immediate surroundings are totally stone free. The fossilized erosion escarpment gradually disappears towards the jainti ja syntyaika. (Kalliomaalausraportteja. Vol. 1) / eds P. Kivikäs, T. Jussila, R. Kupiainen. Jyväskylä, 1999. P. 113-133. 


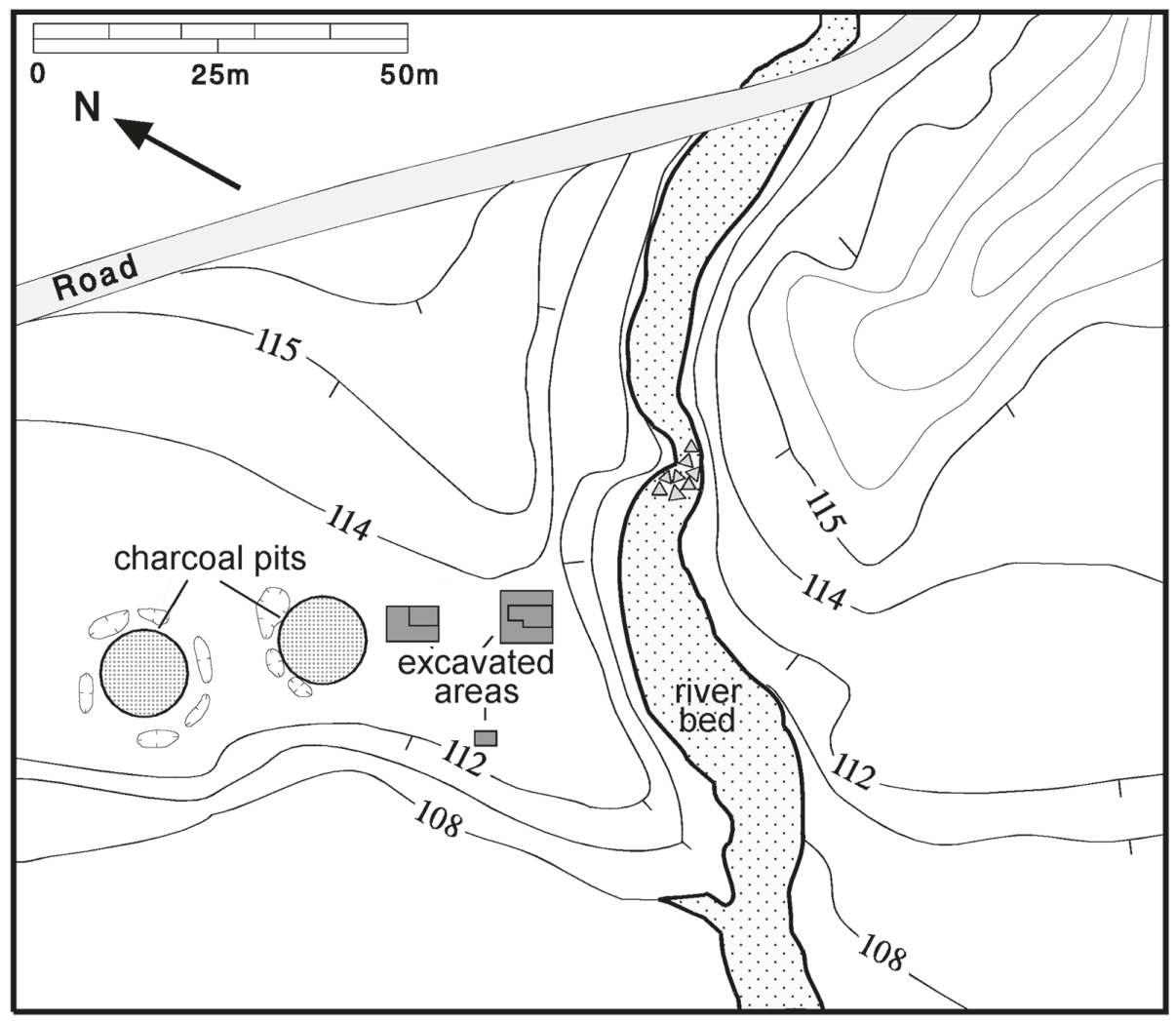

Fig. 3. General map of Helvetinhaudanpuro (map by [Jussila et al., 2007])

northwest as the floor of the ancient lakebed in front of it gradually rises and blends into the gentle slope.

Archaeologist Timo Jussila discovered the fossilized Ancylus escarpment mentioned above in 2000 and visited the location several times during years 2000-2002, digging a number of random test pits at the edge of the escarpment without noticing any traces of prehistoric activity. In the autumn of 2003, the topsoil at the location was partly exposed as a result of logging operations, and when visiting the site again, Jussila observed several quartz flakes and tools indicating the presence of a Stone Age site. The site was not at the edge of the escarpment, as is usual, but about 15-20 metres away from it. Later, during excavations, a number of quartz flakes were found in a test pit on the opposite side of the riverbed. The north-western part of the site was partially destroyed by two $19^{\text {th }}$ century charcoal-pits (Fig. 3).

In the summer of 2004, a small excavation area of $15 \mathrm{~m}^{2}$ was opened up on the spot where the highest concentrations of quartz were observed in patches of revealed mineral soil ${ }^{41}$. In the summer of 2005 , the excavation area was expanded to $48 \mathrm{~m}^{2}$, of which $33 \mathrm{~m}^{2}$ was excavated that year. A small test area of $6 \mathrm{~m}^{2}$ was excavated at the edge of the escarp-

${ }^{41}$ Jussila T., Kriiska A., Rostedt T. Varhaismesoliittisesta asutuksesta Koillis-Savossa - alustavia tuloksia Juankosken Akonpohjan Helvetinhaudanpuron asuinpaikan kiviaineistosta // Arkeologia ja kulttuuri. Uutta kivikauden tutkimuksessa. Arkeologipäivät 2005. Hamina, 2006. P. 50-61. 
ment. The finds from this second area were few and consisted of small quartz flakes. A third area of $7 \mathrm{~m}^{2}$ was opened up 10 meters northwest of the main area, where a small chunk of flint was found in a scarification patch. This area was excavated only to a depth of $5 \mathrm{~cm}$ into the mineral soil, forming a "seed" for forthcoming excavations. Fieldwork continued in 2006, revealing, among other things, some traces of a semi-subterranean rectangular house. The overall size of the site is assumed to be roughly $80 \times 25 \mathrm{~m}^{42}$.

The main excavation area was characterized by a fairly thin podsol soil profile typical of the coniferous forest zone. Distinct coloured cultural layers were not discernible. Ten thousand years of podsolization processes in the loose and sandy soil had eradicated most of the visible traces of original anthropogenic dirt and sooty soil from the surface layers of the topsoil. A weakly outlined but deep pocket of dirty soil in the north-eastern corner of the main excavation area also contained a concentration of small quartz flakes. The find layer was generally $30-35 \mathrm{~cm}$ thick and was located directly below the organic surface layer. In a limited area towards the middle of the main excavation, the find layer reached a depth of 40-45 cm, and in the previously mentioned spot in the north-eastern corner - a depth of $70 \mathrm{~cm}$.

There are two radiocarbon dates from the site, both made from burnt fragment of elk bone: $9200 \pm 75$ BP (Hela-918) - 95\% probability 8606-8285 cal BC and 9275 460 (Hela1406) - $95 \%$ probability $8697-8311$ cal BC (calibrated by OxCal v4.3 $3^{43}$ and the IntCal13 atmospheric calibration curve ${ }^{44}$ ), which corresponds well to the age determination given by shore displacement chronology.

\section{The quartz material from Helvetinhaudanpuro}

The quartz material collected between 2004 and 2006 has been published in previous $\operatorname{articles}^{45}$. Therefore, the focus of this paper is on the description of some special characteristics of the quartz assemblage.

The quartz found at the settlement site varies in colour and quality. The assemblages from Helvetinhaudanpuro sites contain milky as well as almost translucent material. Additionally, different shades of grey and 'smoky' quartz are present. The bulk of the quartz found at the site derives from nodules. Only a small percentage could be interpreted as

${ }^{42}$ Kriiska A., Rostedt T., Jussila T. The Development of Early Mesolithic Social Networks During the Settlement of Virgin Lands in the Eastern Baltic Sea Region- Interpreted through Comparison of Two Sites in Finland // Comparative Perspectives on Past Colonisation, Maritime Interaction and Cultural Integration. (New Directions in Anthropological Archaeology) / eds L. Melheim, H. Glørstad, Z. Glørstad. South Yorkshire, 2016. P. 23.

${ }^{43}$ Bronk Ramsey C. OxCal (computer program). Version 4.23. The Manual. Available: http://c14.arch. ox.ac.uk/oxcal/OxCal.html (accessed: 19.05.2018).

${ }^{44}$ Reimer P. J. et al. IntCal13 and Marine13 radiocarbon age calibration curves 0-50,000 years cal BP // Radiocarbon. 2013. Vol.55, iss. 4. P.1111-1150.

${ }^{45}$ Jussila T., Kriiska A., Rostedt T. Varhaismesoliittisesta asutuksesta Koillis-Savossa - alustavia tuloksia Juankosken Akonpohjan Helvetinhaudanpuron asuinpaikan kiviaineistosta // Arkeologia ja kulttuuri. Uutta kivikauden tutkimuksessa. Arkeologipäivät 2005. Hamina, 2006; Jussila T., Kriiska A., Rostedt T. The mesolithic Settlement in NE Savo, Finland and the earliest Settlement in the Eastern Baltic Sea // Acta Archaeologica. 2007. Vol. 78, iss. 2. P. 143-162; Kriiska A., Rostedt T., Jussila T. The Development of Early Mesolithic Social Networks During the Settlement of Virgin Lands in the Eastern Baltic Sea RegionInterpreted through Comparison of Two Sites in Finland // Comparative Perspectives on Past Colonisation, Maritime Interaction and Cultural Integration. (New Directions in Anthropological Archaeology) / eds L. Melheim, H. Glørstad, Z. Glørstad. South Yorkshire, 2016. P. 19-40. 
vein quartz. There is a simple explanation for this. Namely, we found an abundance of natural quartz nodules close to the settlement site, on the other side of the creek, which would have been easy to transport to the site. The quartz had a rough macrocrystalline structure and was mostly opaque in colour, although some nearly clear and greyish flakes were also detected.

The total amount of quartz found at the site is quite large, consisting of 23981 pieces (Table 1). The material contained mostly flakes (23 506 pieces, $98 \%$ of all quartz material including microdebitage) from which we were able to separate blades (1906 pieces, 8.1\%). We also separated cores (296 pieces, $1.2 \%$ ) and formal tools (179 pieces, $0.7 \%$ ) from the total quartz assemblage.

Table 1. Quartz artefacts from the Helvetinhaudanpuro site

\begin{tabular}{|l|c|c|l|}
\hline Total & 23981 & $99.7 \%$ & of all lithic material \\
\hline Flakes & 23506 & $98.0 \%$ & of total quartz artefacts \\
\hline Blades & 1906 & $8.1 \%$ & of quartz flakes \\
\hline Cores & 296 & $1.2 \%$ & of total quartz artefacts \\
\hline Tools & 179 & $0.7 \%$ & of total quartz artefacts \\
\hline \multicolumn{3}{|l|}{} \\
\hline Identified techniques & 6003 & $25.0 \%$ & of total quartz artefacts \\
\hline Bipolar & 4198 & $69.9 \%$ & of identified techniques in quartz artefacts \\
\hline Platform & 1805 & $30.1 \%$ & of identified techniques in quartz artefacts \\
\hline Flakes & 3348 & $55.8 \%$ & of identified techniques in quartz artefacts \\
\hline Bipolar flakes & 2051 & $61.3 \%$ & of identified quartz flakes \\
\hline Platform flakes & 1297 & $38.7 \%$ & of identified quartz flakes \\
\hline Blades & 2203 & $36.7 \%$ & of identified techniques in quartz artefacts \\
\hline Bipolar blades & 1883 & $85.5 \%$ & of identified quartz blades \\
\hline Platform blades & 320 & $14.5 \%$ & of identified quartz blades \\
\hline Cores & 296 & $4.9 \%$ & of identified techniques in quartz artefacts \\
\hline Bipolar cores & 179 & $53.3 \%$ & of identified quartz cores \\
\hline Platform cores & 157 & $46.7 \%$ & of identified quartz cores \\
\hline Tools, identified & 116 & $1.9 \%$ & of identified techniques in quartz artefacts \\
\hline Bipolar tools & 85 & $73.3 \%$ & of identified quartz tools \\
\hline Platform tools & 31 & $26.7 \%$ & of identified quartz tools \\
\hline Tools, unidentified & 63 & $35.2 \%$ & of quartz tools \\
\hline
\end{tabular}

The fracture properties of quartz make it prone to fragmentation, posing challenges in attempting to determine the reduction technique. It was possible to determine the reduction technique in 6003 items ( $25 \%$ of all quartz artefacts) from Helvetinhaudanpuro. Out of these, 4198 (69.9\%) were manufactured using the bipolar technique (Fig. 4 : 1-3) and 1805 (30.1\%) using the platform technique (Fig. 4: 4-6).

While studying the quartzes, we discovered some exceptional features in items manufactured using the platform technique. First, among the complete long blades we found some pieces without an eraillure scar. The lack of an eraillure scar is possible, but rare when using the basic platform technique in quartz. These unusually shaped flakes and blades are also relatively straight and quite thin for quartz flakes. These features suggest perhaps 

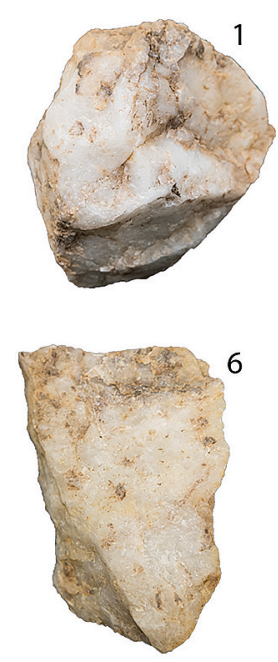
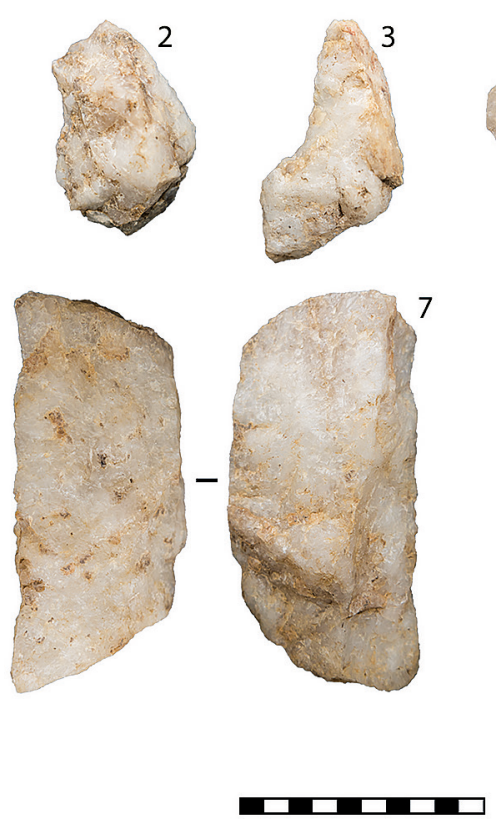

Fig. 4. Some examples of quartz artefacts in Helvetinhaudanpuro:

Bipolar core (1); bipolar flake $(2,3)$; platform core (4); platform flake $(5,6)$; pressure flake $(7$, 8, 10); pressure blade (9) (1 - KM 35473:107, 2 - KM 34661:240, 3 - KM 35473:963, 4 - KM 35473:893, 5 - KM 34661:52, 6 - KM 35473:888, 7 - KM 34661:193, 8 - KM 34661:49b, 9 - KM 35473:440, 10 - KM 34661:225) (photos by Aivar Kriiska, technical realization Kristel Roog)

the difference in percussion, probably even the use of pressure flaking (Fig. 4: 7-10). The signs of pressure flaking in flint and other rock types include regular shape as well as the almost complete absence of compression waves, eraillure scars and bulbs of percussion ${ }^{46}$. These traits are usually hard to detect in quartz, and therefore it is particularly complicated to distinguish direct percussion from indirect percussion in this material. It is difficult, however, to explain the manufacturing of the Helvetinhaudapuro blades in any other way.

Signs of possible pressure flaking were detected only in 41 artefacts $(0,02 \%$ from qurtz artefacts), out of which 24 (59\%) were flakes, 5 (12\%) blades and 12 (29\%) cores. As mentioned, identification of pressure flaking in fragmentary quartz material is complicated and somewhat questionable. Therefore, these figures include only complete or almost complete blades and flakes, which were manufactured using platform percussion. Thus, the actual number of tools produced with pressure flaking is probably larger than the numbers presented above.

The blades, flakes and cores, in which we could detect probable pressure flaking, were relatively large compared to the rest of the material. Their length varied between $3.1-17 \mathrm{~cm}$, width - between $1.1-14,5 \mathrm{~cm}$, and thickness - between $0.5-10.8 \mathrm{~cm}$. The

46 Sørensen M., Rankama T., Kankaanpää J., Knutsson K., Knutsson H., Melvold S., Eriksen B. V., Glørstad H. The First Eastern Migrations of People and Knowledge into Scandinavia: Evidence from Studies of Mesolithic Technology, $9^{\text {th }}-8^{\text {th }}$ Millennium BC // Norwegian Archaeological Review. 2013. Vol. 46, iss. 1. P. 19-56. 

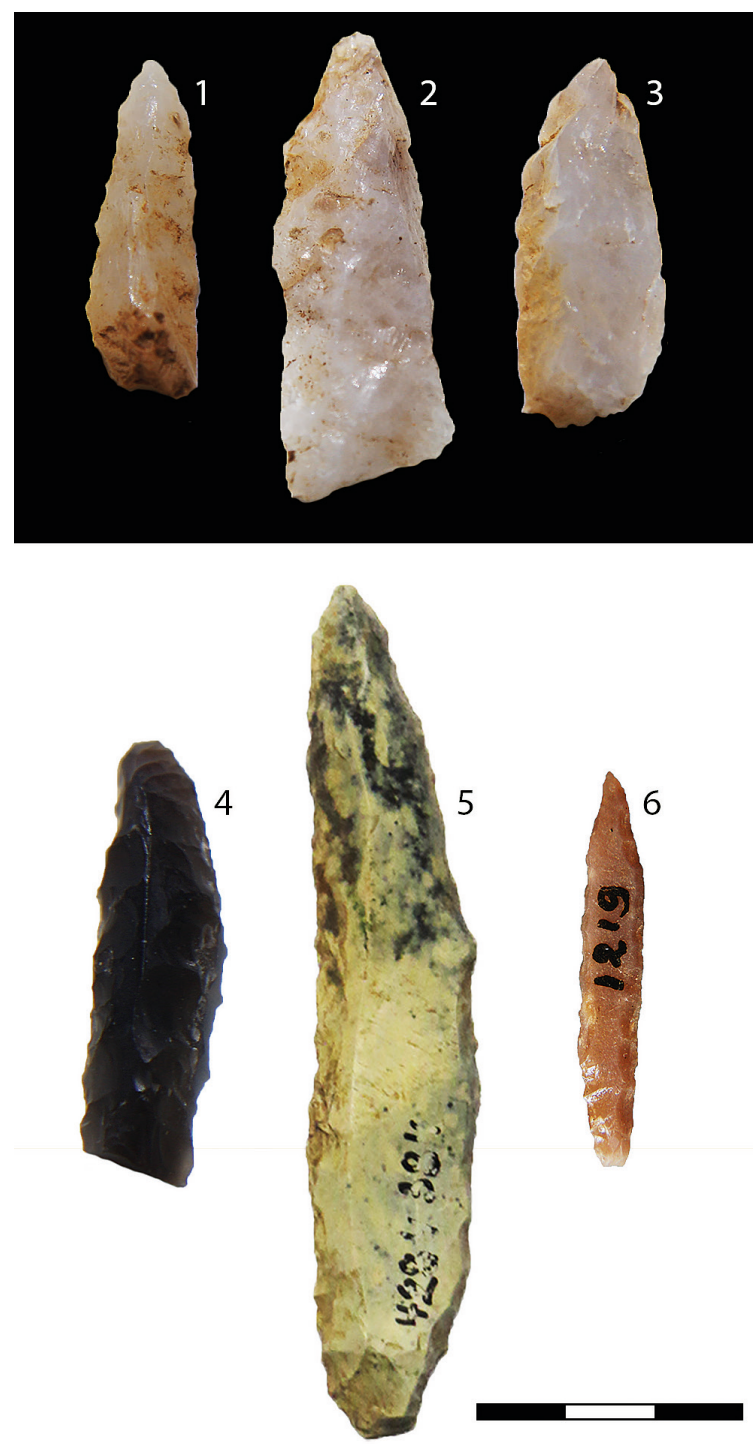

Fig. 5. Narrow retuched quartz and flint points from Helvetinhaudanpuro (1-4), Kunda Lammasmägi (Estonia) (5) and Lotova Gora (Russia) (6) (KM 36024:3305, KM 36024:3310, KM 36024:3319, KM 36024:1, AI 4284:384, 1219) (photos by Aivar Kriiska and Jarmo Kankanpää, technical realization Kristel Roog)

average length was $8,6 \mathrm{~cm}$, width $-6.4 \mathrm{~cm}$, and thickness $-3.2 \mathrm{~cm}$. A large number of cores (10 out of 41) probably explains at least partially the exceptional width and thickness in this material.

It is very difficult to distinguish whether these flakes were made by percussion technique or by, for instance, conical flaking. For clarity, it must be mentioned that in this 
study the conical core pressure blade concept is separated from the subsequent Mesolithic blade concept using keeled cores (often called 'handle cores') ${ }^{47}$.

Another feature detected in the Helvetinhaudanpuro quartz assemblage that also hints to flint technology are the narrow retouched points (Fig. 5: 1-3). There are three of these in total. The points were manufactured from blades or blade fragments, with dimensions ranging between $1.9-3.0 \mathrm{~cm}$ in length, maximum width being between $0.5-1.4 \mathrm{~cm}$, and maximum thickness between $0.4-0.7 \mathrm{~cm}$. The shape of the blade was utilized, and one or two edges exhibit extreme retouching on the dorsal surface. The shape and retouch is quite unusual for quartz. However, flint counterparts have been found in Early Mesolithic settlement sites in the Eastern and Northern European forest zone. In fact, among the lithic material from Helvetinhaudanpuro, there is one flint point (measuring $2.8 \times 0.7 \times 0.5 \mathrm{~cm}$ ) that has been fashioned in the same way as the quartz points (Fig. 5: 4).

Specific groups of artefacts related to the percussion of the quartz is in Helvetinhaudanpuro are 19 anvil stones (see Table 2 and Fig. 6) and three hammerstones. The anvils are relatively soft stones ( 5 on the Mohs' hardness scale) with indentations of different size on one or several sides. The largest of these stones has dimensions of $32.0 \times 21.5 \times 12.0 \mathrm{~cm}$. Most probably, anvil stones were used for bipolar percussion of quartz, but one cannot rule out the possibility of using them in some cases in pressure flaking as platforms, around which a construction withstanding heavier pressure was built.
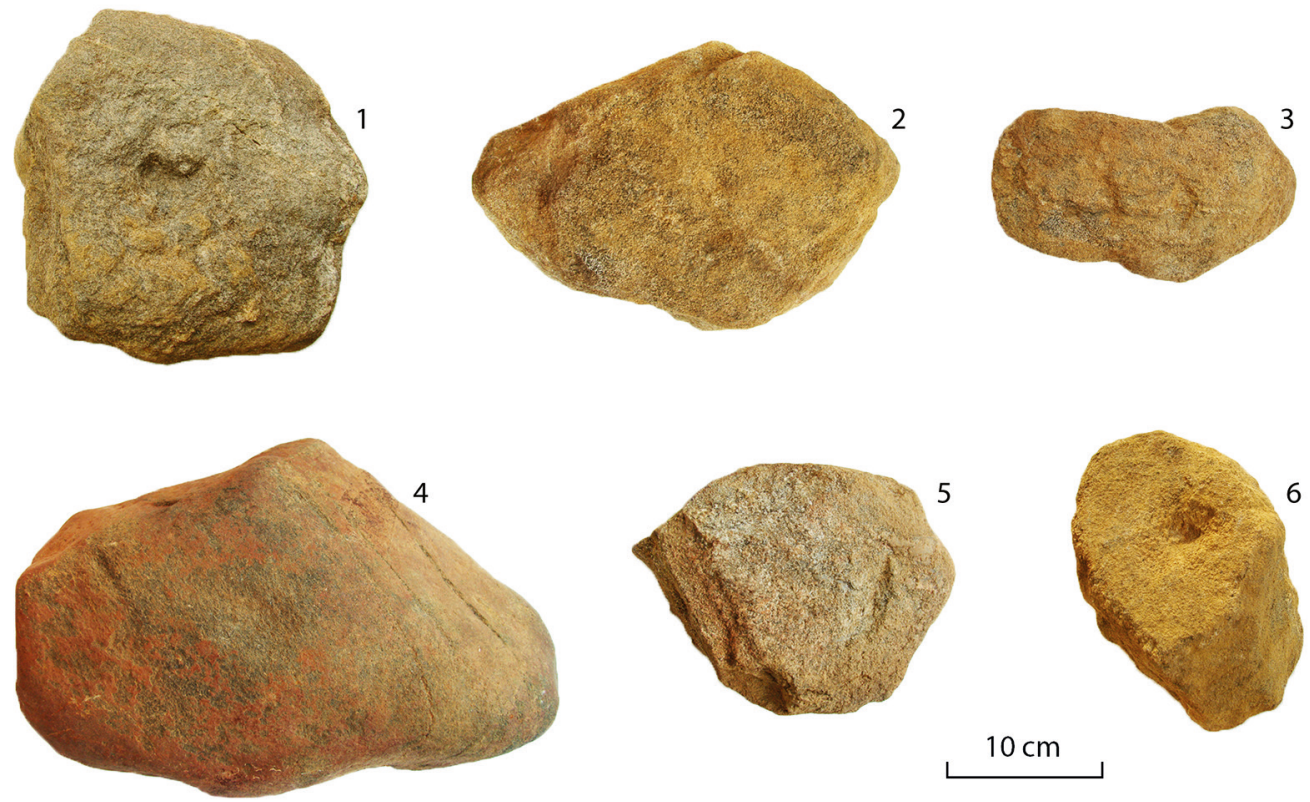

Fig. 6. Anvil stones found from Helvetinhaudanpuro:

1 - KM 36024:2030; 2 - KM 36024:2584; 3 - KM 36024:2029; 4 - KM 36024:2086; 5 - KM 36024:2437; 6 - KM 36024:2583 (photos by Tapani Rostedt and Aivar Kriiska, technical realization Kristel Roog)

47 Sørensen M., Rankama T., Kankaanpää J., Knutsson K., Knutsson H., Melvold S., Eriksen B. V., Glørstad H. The First Eastern Migrations of People and Knowledge into Scandinavia... P. 19-56. 
Table 2. Anvil stones from the Helvetinhaudanpuro site

\begin{tabular}{|c|c|c|c|c|c|c|c|c|c|}
\hline No & $\begin{array}{c}\text { Number of } \\
\text { museum } \\
(\mathrm{KM})\end{array}$ & 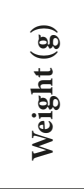 & 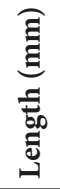 & 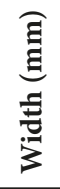 & 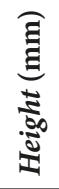 & 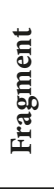 & 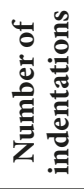 & $\begin{array}{c}\text { Dimension of } \\
\text { indentations }(\mathrm{mm})\end{array}$ & $\begin{array}{c}\text { Smaller } \\
\text { use marks }\end{array}$ \\
\hline 1 & $34661: 244$ & 2950 & 197 & 148 & 60 & $\mathrm{x}$ & 6 & $24-45 \times 18-30 \times 2-8$ & $\mathrm{x}$ \\
\hline 2 & 35473: 521 & 483,2 & 120 & 75 & 65 & $\mathrm{x}$ & 4 & $27-9 \times 17 \times 2-5$ & \\
\hline 3 & 35473: 899 & 538,8 & 142 & 110 & 25 & $\mathrm{x}$ & 2 & $23-26 \times 23-26 \times 4$ & $\mathrm{x}$ \\
\hline 4 & 35473: 1009 & 1060 & 142 & 90 & 60 & & 2 & $30-32 \times 24-26 \times 3-5$ & $\mathrm{x}$ \\
\hline 5 & 35473: 1076 & 7200 & 258 & 178 & 105 & & 2 & $40-45 \times 35-40 \times 2$ & $\mathrm{x}$ \\
\hline 6 & 36024: 586 & 168 & 93 & 60 & 23 & $\mathrm{x}$ & 0 & & $\mathrm{x}$ \\
\hline 7 & 36024: 665 & 3,5 & 23 & 22 & 6 & $\mathrm{x}$ & 1 & $25 \times 25 \times 2$ & \\
\hline 8 & 36024: 2029 & 1390 & 180 & 108 & 60 & & 6 & $26-42 \times 15-33 \times 3-7$ & \\
\hline 9 & 36024: 2030 & 3762 & 210 & 200 & 50 & & 11 & $20-43 \times 20-43 \times 2-8$ & $\mathrm{x}$ \\
\hline 10 & 36024: 2031 & 253 & 87 & 60 & 34 & $\mathrm{x}$ & 1 & $13 \times 9 \times 2$ & $\mathrm{x}$ \\
\hline 11 & 36024: 2033 & 1655 & 180 & 126 & 45 & & 2 & $33-51 \times 22-26 \times 3-5$ & $\mathrm{x}$ \\
\hline 12 & 36024: 2034 & 4021 & 237 & 126 & 104 & & 1 & $47 \times 40 \times 4$ & $\mathrm{x}$ \\
\hline 13 & 36024: 2035 & 745 & 105 & 98 & 70 & & 8 & $28-42 \times 24-28 \times 4-7$ & $\mathrm{x}$ \\
\hline 14 & 36024: 2086 & 9300 & 320 & 215 & 120 & & 1 & $59 \times 47 \times 4$ & $\mathrm{x}$ \\
\hline 15 & 36024: 2437 & 638 & 109 & 81 & 56 & & 2 & $16-25 \times 12-17 \times 2-4$ & $\mathrm{x}$ \\
\hline 16 & 36024: 2582 & 842 & 85 & 79 & 71 & & 6 & $19-42 \times 14-36 \times 3-8$ & $\mathrm{x}$ \\
\hline 17 & 36024: 2583 & 1546 & 146 & 97 & 68 & & 8 & $24-41 \times 24-41 \times 4-8$ & $\mathrm{x}$ \\
\hline 18 & 36024: 2584 & 5450 & 200 & 145 & 97 & & 10 & $18-36 \times 9-30 \times 3-5$ & $\mathrm{x}$ \\
\hline 19 & 36024: 3253 & 2600 & 177 & 165 & 53 & & 1 & $20 \times 20 \times 2$ & \\
\hline
\end{tabular}

\section{Discussion and conclusion}

Human curiosity and creativity, the ability to create 'friendly model environments in hostile environments', and first and foremost, the ability to decide whether to be innovative or conservative makes every one of us a unique creature. Nevertheless, it is difficult to imagine a society that can function by itself without having any impact on its surroundings. Shelter, clothing, nourishment and overall life style are largely dependent on the environment. In fact, the challenges of and adaptations to the environment are reflected in one way or another in almost every aspect of human society ${ }^{48}$. Anyhow, humans do not just passively adapt to their environments, but they also shape them. People from different cultures shaped and took advantage of their environments in a variety of ways. These differences can be seen in both technology and the way in which people experience their surroundings. Relying solely on ecological models of human-environ-

48 Nuñez M., Okkonen J. Environmental Background for the Rise and Fall of Villages and Megastructures in North Ostrobotnia 4000-2000 cal BC // Dig it all. Papers dedicated to Ari Siiriäinen / ed. by M. Huurre, Jyväskylä, 1999. P.112; Rankama T. The colonization of northernmost Finnish Lappland and the inland areas of Finnmark // Mesolithic on the Move / eds L. Larsson, H. Kindgren, K. Knutsson, D. Loeffler and A. Åkerlund. Oxford, 2003. P.43-44. 
ment relationships is always questionable, because archaeologists create these models based on their own cultural experiences, unconsciously or not ${ }^{49}$.

To create an accurate image of society, it is necessary to study, for instance, how economic and technological changes impact the social structures of societies. In this way, society is seen as a complex entity with constant and daily conflicts in between challenges and needs. Personal challenges, ancestral customs and social norms created by society become the influencers. Thus, society is not viewed as a coherent unit, but rather as a loose alliance where every individual has a function and needs. Through compromise and adaptation, together they create the society and its image to the outside world ${ }^{50}$.

The reasons for temporal-geographic shifts and changes within society should be looked for not only in ecological explanations but also in internal sociocultural actors. Both approaches can be studied independently, but for better results, it is beneficial to everyone to compare the interdependence of the two. In this way, it is possible to avoid the overuse of environmental determinism, in which the natural environment is seen as the main factor that shapes culture.

In the Helvetinhaudanpuro material, we detected characteristics connected to adaptation to the local raw material - quartz - but the material also contained technical achievements and tool shapes which indicate a deeper socio-cultural background. Technology is a vital research tool when attempting to understand the persistence of occupation and social connections in cases where the raw materials change. In Finland, we are only at the beginning of understanding the earliest occupation, currently concentrating on collecting and describing the empirical evidence, but we should also keep in mind the long-term goal of studying the diversity of the society. The Helvetinhaudanpuro material has strong explanatory potential for studying the beginning of the local habitation.

The area of Finland was first inhabited after the last Ice Age, according to the newest data, approximately soon after $9000 \mathrm{cal} \mathrm{BC}^{51}$. The peopling of Finland was part of the rapid colonisation of the Eastern and Northern European forest zone, extending from the Baltic Sea all the way to the Urals. In the early phases of colonisation, close contact with the homeland continued, and through wide social networks, raw materials, particularly flint, were also exchanged. For instance, flint makes up almost half of the lithics at the Saarenoja 2 settlement site in Southern Finland, the only Early Mesolithic site in this micro region with a relatively short occupation period (c. $8700 \mathrm{cal} \mathrm{BC})$ that has been extensively excavated to date ${ }^{52}$.

49 Uleberg E. Cultural Landscapes in Stone Age Research // The Mesolithic of Central Scandinavia / ed by J. Boaz. Oslo. 1999. P. 41; Welinder S. Människor och landskap. (Aun, vol. 15). Uppsala, 1992. P. 63.

50 Tilley C. Conceptual Frameworks for the explanation of Sosio-cultural Change // Pattern of the Past / eds I. Hodder I, G. Isaac, N. Hammond. Cambridge. 1981. P. 368.

${ }_{51}$ Pesonen P., Hertell E., Simponen L., Mannermaa K., Manninen M. A., Rostedt T., Taipale, N., Tallavaara M. Postglacial pioneer settlement in the Lake Sarvinki area, eastern Finland. Lateglacial and Postglacial Pioneers in Northern Europe // British Archaeological Reports, International Series. Vol.2599. Oxford, 2014. P. 174-190; Kriiska A., Rostedt T., Jussila T. The Development of Early Mesolithic Social Networks During the Settlement of Virgin Lands in the Eastern Baltic Sea Region-Interpreted through Comparison of Two Sites in Finland // Comparative Perspectives on Past Colonisation, Maritime Interaction and Cultural Integration (New Directions in Anthropological Archaeology). South Yorkshire, 2016. P. 34.

52 Kriiska A., Rostedt T., Jussila T. The Development of Early Mesolithic Social Networks During the Settlement of Virgin Lands in the Eastern Baltic Sea Region- Interpreted through Comparison of Two Sites in Finland // Comparative Perspectives on Past Colonisation, Maritime Interaction and Cultural Integration. (New Directions in Anthropological Archaeology). South Yorkshire, 2016. P. 25. 
Flint does not occur naturally in Finland and therefore quartz usually became the substitute for it in southernmost Finland. The shift in raw materials took place within a few hundred years and appears to have coincided with the change in social networks related to the break in connections with the homeland ${ }^{53}$. Helvetinhaudanpuro belongs to the second phase of early colonisation of Finland, for which one of the characteristics is the use of local materials. Foreign raw materials, in particular flint, make up a marginal amount of the material excavated $(0.07 \%$ of the total lithic assemblage). There is no reason to doubt that the first settlers of Helvetinhaudanpuro had already been using quartz before arriving at the site. Some of the signs indicating that people were already familiar with quartz are the overall mastery of quartz reduction and several carefully crafted quartz objects that would not have been of such high quality if the population was just experimenting with quartz knapping ${ }^{54}$.

The quartz techniques seen in Helvetinhaudanpuro are very similar to those from other Finnish Mesolithic sites - bipolar technique dominates, but platform percussion was also used to some extent ${ }^{55}$. However, some items are unusual, even special, and more comparable to flint than quartz material.

In both materials, tools are dominated by scrapers, but what connects the two technologically and morphologically events are the Helvetinhaudanpuro points. To our knowledge, no quartz counterparts have been found to date in other parts of Finland. Similar points from flint have been found in Saarenoja 2 (see Fig. 5: 5) and Lahti Ristola in Finland, in Kunda Lammasmägi (see Fig. 5: 5) and Pulli in Estonia, as well as in Veschevo 2 on the Karelian Isthmus and Lotova Gora (information from Tuija Rankama and Jarmo Kankaanpää) (see Fig. 5: 6) on the Vologda region in Russia. ${ }^{56}$

The second characteristic of the Helvetinhaudanpuro assemblage is the possible use of pressure flaking in quartz knapping. The abnormally straight blades and flakes lacking eraillure scars as well as some cores are an indicator of pressure flaking, but proving this hypothesis requires further research and experimental knapping. If indeed we have evidence of pressure flaking, then this assemblage is unique with no precedents in Finland or the Eastern Baltic.

Pressure flaking is generally associated with other lithics than quartz. Pressure flaking was used with the intention of producing an abundance of tools or blanks ${ }^{57}$. Pressure

53 Ibid. P. 34.

${ }^{54}$ Knutsson H., Knutsson K., Molin F., Zetterlund P. From flint to quartz: Organisation of lithic technology in relation to raw material availability during the pioneer process of Scandinavia // Quaternary International. 2016. Vol. 424. P. 32-57.

55 Jussila T., Kriiska A., Rostedt T. The mesolithic Settlement in NE Savo, Finland and the earliest Settlement in the Eastern Baltic Sea // Acta Archaeologica. 2007. Vol.78, iss. 2. P. 143-162; and the literature mentioned there.

56 Jussila T., Kriiska A., Rostedt T. Saarenoja 2 - An Early Mesolithic Site in South-Eastern Finland: Preliminary Results and Interpretations of Studies Conducted in 2000 and 2008-10 // Fennoscandia archaeological. 2012. Vol. XXIX. P. 3-27; Takala H. The Ristola Site in Lahti and the Earliest Postglacial Settlement of South Finland. Jyväskylä, 2003.

57 Sørensen M. Teknologiske traditioner I Maglemosekulturen. En diakron analyse av Maglemosekulturens flækkeindustri // Stenalderstudier. Tidlig Mesolitiske jægere og samlere i Sydskandinavien / ed. by E. B. V. Århus. Jutland Archaeological Society. 2006. P. 19-77; Sørensen M. The Arrival and Development of Pressure Blade Technology in Southern Scandinavia // The Emergence of Pressure Blade Making. From Origin to Modern Experimentation / ed. by P. M. Desrosiers. New York, 2012. P.237-260; Sulgostowska Z. The Earliest Mesolithic Settlement in North-Eastern Poland // The Earliest Settlement in Scandinavia. Acta Archaeologica Lundensia. Series in 8, no. 24. Stockholm, 1996. P. 297-305; Sulgostowska Z. Final Palaeolithic 
flaking is not commonly seen in the early colonisation wave in Finland, but there is evidence of its use in the lithic material from the Early Mesolithic Sujala in Utsjoki ${ }^{58}$, Jokivarsi 1 in Eno and Saarenoja 2 in Lappeenranta ${ }^{59}$ settlement sites. The raw material used in Sujala was metamorphic sand stone, whereas flint was the raw material used at the Jokivarsi in Eno, Ristola in Lahti and Saarenoja 2 in Lappeenranta settlement sites.

Pressure flaking in itself is an unusual lithic reduction method. Experimental archaeological studies have shown that adopting the technique does not take very long. In fact, the technique is learned faster than freehand percussion. Once the tools and constructions required had been manufactured, detaching blades from the core by applying pressure was actually a relatively simple process ${ }^{60}$.

The dating of pressure flaking varies in Eurasia. The technique is considered to have originated in Paleolithic Mongolia more than 20,000 years ago ${ }^{61}$. The oldest dates from Europe derive from the Eastern European Forest zone from where the technique seems to have spread to the west ${ }^{62}$. The earliest evidence near Finland dates to the Early Mesolithic, c. $9000 \mathrm{cal} \mathrm{BC}$ or slightly later. It coincides with the earliest Mesolithic colonisation of the Eastern and Northern European Forest zone (the Pulli period, c.9000-8500 cal $\mathrm{BC}$ ) and with the subsequent period when local cultures (e.g. Butovo, Kunda, Veretye) had already been developed. Pressure flaking was in use during the Mesolithic in both Russia and the Eastern Baltic ${ }^{63}$.

Masovian Cycle and Mesolithic Kunda Culture Relations // Tanged points cultures in Europe. Read at the international Archaeological Symposium, Lublin, September 13-16, 1993. Lublin, 1999. P. 85-93.

${ }_{58}$ Rankama T., Kankaanpää J. Eastern arrivals in post-glacial Lappland: The Sujala site 10000 cal BP // Antiquity. 2008. Vol. 82. P. 884-900.

${ }_{59}$ Jussila T., Kriiska A., Rostedt T. Saarenoja 2 - An Early Mesolithic Site in South-Eastern Finland: Preliminary Results and Interpretations of Studies Conducted in 2000 and 2008-10 // Fennoscandia archaeological. 2012. Vol. XXIX. P. 15.

60 Pelegrin J. Prehistoric lithic technology: some aspects of research // Archaeological Review from Cambridge. 1990. Vol.9, iss. 1. P.116-125; Sørensen M. The Arrival and Development of Pressure Blade Technology in Southern Scandinavia // The Emergence of Pressure Blade Making. From Origin to Modern Experimentation / ed. by P. M. Desrosiers. New York. 2012. P.250; Sørensen M. et al. The First Eastern Migrations of People and Knowledge into Scandinavia: Evidence from Studies of Mesolithic Technology, $9^{\text {th }}-8^{\text {th }}$ Millennium BC // Norwegian Archaeological Review. 2013. Vol. 46, iss. 1. P. 23.

${ }^{61}$ Inizan M.-L. Pressure débitage in the old world: forerunners, researchers, geopolitics - handing on the Baton // The Emergence of Pressure Blade Making. From Origin to Modern Experimentation. New York, 2012. P. 11-43; Darmark K. Surface Pressure Flaking in Eurasia: Mapping the Innovation, Diffusion and Evolution of a Technological Element in the Production of Projectile Points // The Emergence of Pressure Blade Making. From Origin to Modern Experimentation. New York, 2012. P.261-284.

62 Sørensen M., Rankama T., Kankaanpää J., Knutsson K., Knutsson H., Melvold S., Eriksen B. V., Glørstad H. The First Eastern Migrations of People and Knowledge into Scandinavia: Evidence from Studies of Mesolithic Technology, 9th-8th Millennium BC // Norwegian Archaeological Review. 2013. Vol. 46, iss. 1. P. 19-56.

${ }^{63}$ Oshibkina $S$. V. Tanged point industries in the northwest Russia. // Tanged points cultures in Europe. Read at the international Archaeological Symposium, Lublin, September 13-16, 1993. Lublin, 1999. P.325-336; Koltsov L. V., Zhilin M. G. Tanged point cultures in the upper Volga basin. Tanged points cultures in Europe Lublin, 1999. P.346-360; Zhilin M. G. Early Mesolithic communication networks in the East European forest zone // Mesolithic on the Move. Oxford, 2003. P.688-693; Zhilin M. G. The terminal Paleolithic - Early Mesolithic of the Upper Volga and colonization of the north-west of eastern Europe // Pioneer settlement and colonization Processes in the Barents Region. Vuollerim papers on Hunter-Gatherer Archaeology. Vol. 1. Vuollerim, 2005. P. 163-179; Kriiska A., Lõhmus M. Archaeological fieldwork on Kivisaare Stone Age burial ground and settlement site // Archaeological fieldwork in Estonia 2004. Tallinn, 2005. P. 31-43. 
Pressure flaking is one of many techniques and formal similarities that connected these areas in the Early Mesolithic. The similarities in lithic technology also include the conical core pressure blade concept, flint arrowheads with a tang and retouch on the ventral side of edge, flint edge burins on blades, flint chisels etc. ${ }^{64}$

The same wide distribution area is seen in bone tools and technology, particularly with regard to arrowheads ${ }^{65}$. The acidic nature of the soil in Finland causes rapid deterioration of organic materials and therefore only burned bones usually survive. Because of this problem, only two tools have been found that can be securely assigned to the Early Mesolithic based on typology: a tip fragment of an arrowhead with a biconical head and several fragments of slotted point from Lappeenranta Muilamäki. Flint inserts associated with slotted points have been found in many locations: Saarenoja 2 (ca. 10\% of all flint tools from the site), Muilamäki, Helvetinhaudanpuro, Lahti Ristola and Eno Jokivarsi 1 settlement sites ${ }^{66}$. There is at least one quartz insert from Helvetinhaudanpuro (NM 36024:3316, bipolar flake measuring $2.7 \times 0.5 \times 0.2 \mathrm{~cm}$ ).

To sum up, the quartz assemblage from the Helvetinhaudanpuro settlement site, dating approximately to $8500 \mathrm{cal} \mathrm{BC}$, is a unique link between flint and quartz knapping technology. The material is diverse and representative, and due to the short occupation sequence this site is an exceptional location for studying the early period of change in raw materials in Finland.

The majority of the quartz artefacts from the site are analogous to the 'normal' and previously described quartz material from Finnish Mesolithic sites younger than Helvetinhaudanpuro. Nevertheless, the assemblage contains retouched points and insert from quartz that seem to connect the material more to flint than quartz and through this to older settlements in Finland and wider areas in Eastern and Northern Europe. It appears that pressure techniques usually associated with flint knapping were adopted for use in quartz knapping at the Helvetinhaudapuro site, at least for a while. This is a very unusual feature in quartz reduction, and in fact, the first possible evidence from Finland, Russian Karelia and Estonia for this technological 'memory' from the initial colonisation period in the Early Mesolithic.

\section{References}

Ailio J. Die Steinzeitliche Wohnplatzfunde in Finland I-II. Helsingfors, Kommission bei der Akademischen Buchhandlung, 1909, 394 p.

${ }^{64}$ Ostrauskas T. Mesolithic Kunda Culture. A glimpse from Lithuania // De temporibus antiquissimis ad honorem Lembit Jaanits (Muinasaja teadus, vol.8). Tallinn, 2000. P.67-180; Jussila T., Kriiska A., Rostedt T. Saarenoja 2 - An Early Mesolithic Site in South-Eastern Finland: Preliminary Results and Interpretations of Studies Conducted in 2000 and 2008-10 // Fennoscandia archaeological. 2012. Vol. XXIX. P. 3-27; Sørensen M. et al. The First Eastern Migrations of People and Knowledge into Scandinavia: Evidence from Studies of Mesolithic Technology, 9th-8th Millennium BC // Norwegian Archaeological Review. 2013. Vol. 46, iss. 1. P. 19-56.

65 Ibid. P. 19-56; Zhilin M. Early Mesolithic bone arrowheads from the Volga-Oka interfluve, Central Russia // Fennoscandia archaeological. 2015. Vol.XXXII. P.35-54.

${ }^{66}$ Kriiska A., Rostedt T., Jussila T. The Development of Early Mesolithic Social Networks During the Settlement of Virgin Lands in the Eastern Baltic Sea Region- Interpreted through Comparison of Two Sites in Finland // Comparative Perspectives on Past Colonisation, Maritime Interaction and Cultural Integration (New Directions in Anthropological Archaeology) / eds L. Melheim, H. Glørstad, Z. Glørstad. South Yorkshire, 2016. P. 27. 
Andrefsky W. Jr. Raw-material availability and the organization of technology. American Antiquity, 1994, vol. 59, iss. 1, pp. 21-34.

Andrefsky W. Jr. Lithics. Macroscopic approaches to analysis (Cambridge Manuals in Archaeology). Cambridge, 1998, 326 p.

Bamforth D. B. Technological efficiency and tool curation. American Antiquity, 1986, vol.51, iss. 1, pp.3850.

Bleed P. The Optimal Design of Hunting Weapons: Maintainability or Reliability. American Antiquit, 1986, vol. 51, iss. 4, pp. 737-747.

Brantingham P. J., Olsen J.W., Rech J.A. and Krivoshapkin A.I. Raw Material Quality and Prepared Core Technologies in Northeast Asia. Journal of Archaeological Science, 2000, vol. 27, pp. 255-271.

Callahan E. An evaluation of the lithic technology in middle Sweden during the Mesolithic and Neolithic (Aun, vol. 8). Uppsala, Societas Archaeologica Upsaliensis, 1987, 72 p.

Callahan E., Forsberg L., Knutsson K., Lindgren C. Frakturbilder. Kulturhistoriska kommentarer till det säregna sönderfallet vid bearbetning av kvarts. Tor, 1992, vol. 24, pp. 27-63.

Crabtree D. E. An introduction to the technology of stone tools (Occasional papers of the museum, number 28). Pocatello, Idaho, Idaho State University, 1972. 98 p.

Darmark K. Surface Pressure Flaking in Eurasia: Mapping the Innovation, Diffusion and Evolution of a Technological Element in the Production of Projectile Points. The Emergence of Pressure Blade Making. From Origin to Modern Experimentation. Ed. by P. M. Desrosiers. New York, 2012, pp. 261-284.

Eskola P. Kidetieteen, mineralogian ja geologian alkeet. Porvoo, Werner Söderström Osakeyhtiö, 1957. 337 p.

Europaeus A. Ojalankankaan kivikauden löytöpaikka Alavudella. Suomen Museo 1916. Helsinki, 1919, pp. 73-82.

Gero J.M. Assessing social information in material objects: how well do lithics measure up? Time, energy and stone tools. Ed. by R. Torrence. Cambridge, Cambridge University Press, 1989, pp. 92-105.

Hayden B. Practical and Prestige Technologies: The Evolution of Material Systems. Journal of Archaeological Method and Theory, 1998, vol. 5, iss. 1, pp.1-55.

Hertell E., Manninen M. A. Rävåsens kvartsmaterial. Finskt Museum 2002. Helsinki, 2005, pp. 84-100.

Hertell E., Tallavaara M. High Mobility or Gift Exchange: early Mesolithic chipped lithics in Southern Finland. Mesolithic interfaces: Variability in lithic technologies in eastern Fennoscandia. Ed. by T. Rankama. Saarijärvi, The Archaeological Society of Finland, 2011, pp.11-41.

Inizan M.-L. Pressure débitage in the old world: forerunners, researchers, geopolitics - handing on the Baton. The Emergence of Pressure Blade Making. From Origin to Modern Experimentation. Ed. by P. M. Desrosiers. New York, 2012, pp. 11-43.

Jussila T. Saimaan kalliomaalausten ajoitus rannansiirtymiskronologian perusteella. Saimaan ja Päijänteen alueen kalliomaalausten sijainti ja syntyaika. (Kalliomaalausraportteja 1). Ed. by P. Kivikäs, T. Jussila, R. Kupiainen. Jyväskylä, Kivikäs - muinaistaidekeskus, 1999, pp. 113-133.

Jussila T., Kriiska A., Rostedt T. Varhaismesoliittisesta asutuksesta Koillis-Savossa - alustavia tuloksia Juankosken Akonpohjan Helvetinhaudanpuron asuinpaikan kiviaineistosta. Arkeologia ja kulttuuri. Uutta kivikauden tutkimuksessa. Arkeologipäivät 2005. Ed. by T. Mökkönen \& P. Pesonen. Hamina, Suomen Arkeologinen Seura, 2006, pp. 50-61.

Jussila T., Kriiska A., Rostedt T. The mesolithic Settlement in NE Savo, Finland and the earliest Settlement in the Eastern Baltic Sea. Acta Archaeologica 2007, vol. 78, iss. 2, pp. 143-162.

Jussila T., Kriiska A., Rostedt T. Saarenoja 2 - An Early Mesolithic Site in South-Eastern Finland: Preliminary Results and Interpretations of Studies Conducted in 2000 and 2008-10. Fennoscandia archaeologica, 2012, vol.XXIX, pp.3-27.

Kankaanpää J.\& Rankama T. Early Mesolithic Pioneers in Northern Finnish Lappland. Pioneer Settlements and Colonization Processes in the Barents Region. (Vuollerim Papers on Hunter-Gatherer Archaeology 1). Ed. by H. Knutsson. Vuollerim, Vuollerim 6000 År, 2005, pp. 109-161.

Kankaanpää J., Rankama T. Spatial Patterns of the Early Mesolithic Sujala Site, Utsjoki, Finnish Lappland. Mesolithic interfaces: Variability in lithic technologies in eastern Fennoscandia. Ed. by T. Rankama. Saarijärvi, The Archaeological Society of Finland, 2011, pp. 42-63.

Kelly R. L. The three sides of a biface. American Antiquity, 1988, vol.53, pp.717-734.

Koltsov L. V., Zhilin M. G. Tanged point cultures in the upper Volga basin. Tanged points cultures in Europe. Eds S. K. Kozlowski, J. Gurba, L. L. Zalisnyak. Lublin, Maria Curie-Skłodowska, 1999, pp. 346-360.

Knutsson K. Making and using stone tools. The analysis of the lithic assemblages from the Middle Neolithic sites with flint in Västerbotten, northern Sweden. (Aun, vol. 11). Uppsala, Societas Archaeologica Upsaliensis, 1988, $206 \mathrm{p}$. 
Knutsson K. Garaselet-Lappviken-Rastklippan. Introduktion till en diskurssion om Norrlands Äldsta Bebyggelse. Tor, 1993, vol. 25, pp. 5-51.

Knutsson H., Knutsson K., Molin F., Zetterlund P. From flint to quartz: Organisation of lithic technology in relation to raw material availability during the pioneer process of Scandinavia. Quaternary International, 2016, vol.424, pp. 32-57.

Kriiska A., Lõhmus M. Archaeological fieldwork on Kivisaare Stone Age burial ground and settlement site. Archaeological fieldwork in Estonia 2004. Tallinn, Muinsuskaitseamet, 2005, pp. 31-43.

Kriiska A., Rostedt T., Jussila T. The Development of Early Mesolithic Social Networks During the Settlement of Virgin Lands in the Eastern Baltic Sea Region- Interpreted through Comparison of Two Sites in Finland. Comparative Perspectives on Past Colonisation, Maritime Interaction and Cultural Integration. (New Directions in Anthropological Archaeology). Eds L. Melheim, H. Glørstad, Z. Glørstad. South Yorkshire, Equinox publishing, 2016, pp. 19-40.

Kuhn S. L. Mousterian lithic technology. Princeton, Princeton University Press, 1995, 209 p.

Luho V. Die Askola-Kultur. Die frühmesolitische Steinzeit in Finnland. Suomen Muinaismuistoyhdistyksen Aikakauskirja. Vol.57. Helsinki, Suomen Muinaismuistoyhdistys, 1956, 167 p.

Luho V. Die Suomusjärvi-Kultur. Die mittel- und spätmesolitische zeit in Finnland. Suomen Muinaismuistoyhdistyksen Aikakauskirja. Vol.66). Helsinki, Suomen Muinaismuistoyhdistys, 1967, $124 \mathrm{p}$.

Manninen M. A., Tallavaara M., Hertell E. Subneolithic bifaces and flint assemblages in Finland. Outlining the history of research and future questions. Uniting Sea. Stone Age societies in the Baltic Sea region. (Papers in Archaeology, vol.33). Eds C. Samuelsson, N. Ytterberg Occasional. Uppsala, Uppsala Universitet, 2003, pp. 161-179.

Manninen M.A. Culture, Behavior and the 8200 cal BP Cold Event. Organisational Change and Culture-environmental Dynamics in Late Mesolithic Northern Fennoscandia. (Monographs of the Archaeological Society of Finland, vol. 4.) Helsinki, Archaeological society of Finland, 2014, 87 p.

Manninen M.A., Knuttson K. Lithic raw material diversification as an adaptive strategy - Technology, mobility and site structure in Late Mesolithic northernmosts Europe. Journal of Athropological Archaeology, 2014, vol. 33, pp. 84-98.

Matiskainen H. Beiträge zur Kentnisse der mesolitischen Schrägschneidepfeile und Mikrolithen aus Quarz. Studia praehistorica Fennica C F Meinander septuagenario dedicata. ISKOS, vol. 6. Ed. by T. Edgren. Helsinki, Suomen muinaismuistoyhdistys, 1986, pp.77-98.

Matiskainen H. The Palaeoenvironment of Askola, Southern Finland. Mesolithic Settlement and Subsistence 10000-6000 b.p. (ISKOS, vol. 8). Helsinki, Suomen muinaismuistoyhdistys, 1989, 97 p.

Nelson M. C. The Study of Technological Organization. Archaeological Method and Theory, vol. 3, iss. 1. Ed. by M. B. Schiffer. Arizona, University of Arizona Press, 1991, pp. 57-100.

Nuñez M., Okkonen J. Environmental Background for the Rise and Fall of Villages and Megastructures in North Ostrobotnia 4000-2000 cal BC. Dig it all. Papers dedicated to Ari Siiriäinen. Ed. by M. Huurre. Jyväskylä, Finnish Antiquarian Society and Archaeological Society of Finland, 1999, pp. 105-115.

Olofsson A. Early Colonization of Northern Norrland: Technology, Chronology, and Culture. Pioneer Settlement in the Mesolithic of Northern Sweden. (Archaeology and Environment 16). Umeå, Umeå University Department of Archaeology and Sami Studies, 2003, 159 p.

Oshibkina S. V. Tanged point industries in the northwest Russia. Tanged points cultures in Europe. Read at the international Archaeological Symposium, Lublin, September 13-16, 1993. Eds S. Kozlowski, J. Gurba, L. I.Zalisnyak. Lublin, Maria-Curie Sklodowska University Press, 1999, pp. 325-336.

Ostrauskas T. Mesolithic Kunda Culture. A glimpse from Lithuania. De temporibus antiquissimis ad honorem Lembit Jaanits. Vol. 8: Muinasaja teadus. Eds V.Lang, A. Kriiska. Tallinn, Ajaloo Instituut, 2000, pp. 67-180.

Pankrušev G. A. Karjalan mesolittinen ja neolitttinen kausi. Vol. 1. Helsinki, Mesoliittinen kausi,1994, 122 p.

Parry W. J., Kelly R. L. Expedient Core Technology and Sedentism. The Organization of Core Technology. Eds J. K. Johnson, C. A. Morrow. Boulder, Westview Press, 1987, pp. 285-304.

Pelegrin J. Prehistoric lithic technology: some aspects of research. Archaeological Review from Cambridge, 1990, vol. 9, issue. 1, pp. 116-125.

Pelegrin J. Blade-Making Techniques from the Old World: Insights and Applications to Mesoamerican Obsidian Lithic Technology. Mesoamerican Lithic Technology: Experimentation and interpretation. Ed. by K. Hirth. Salt Lake City, University of Utah Press, 2003, pp. 55-71.

Pesonen P., Tallavaara M. Esihistoriallinen leiripaikka Lohjan Hossanmäellä- kvartseja ja yllättäviä ajoituksia. Suomen Museo 2005. Helsinki, 2006, pp.5-26. 
Pesonen P., Hertell E., Simponen L., Mannermaa K., Manninen M. A., Rostedt T., Taipale, N., Tallavaara M. Postglacial pioneer settlement in the Lake Sarvinki area, eastern Finland. Lateglacial and Postglacial Pioneers in Northern Europe. (British Archaeological Reports, International Series, vol.2599). Eds F. Riede, M. Tallavaara. Oxford, Archaeopress, 2014, pp. 174-190.

Pälsi S. Palomäen kivikautinen asuinpaikka Urjalassa. Suomen Museo 1913. Helsinki, 1913, pp. 63-79.

Rajala U. Kvartsiteknologian tutkiminen ja luokittelu Turun Niuskalan Kotirinteen kiukaiskeraamisen asuinpaikan vuosien 1983 ja 1984 kvartsilöydöt. Unpublished Master's thesis, University of Turku. Turku, $1995,129 \mathrm{p}$.

Rankama T. Ala-Jalve. Spatial, technological, and behavioral analyses of the lithic assemblage from a Stone Age Early Metal Age site in Utsjoki, Finnish Lapland. British Archaeological Reports International Series. Vol.681. Oxford, Archaeopress, 1997, 146 p.

Rankama T. Analyses of the Quartz Assemblages of Houses 34 and 35 at Kauvonkangas in Tervola. Huts and Houses. Stone Age and Early Metal Age Buildings in Finland. Ed. by H. Ranta. Helsinki, National Board of Antiquities, 2002, pp. 79-108.

Rankama T. The colonization of northernmost Finnish Lappland and the inland areas of Finnmark. Mesolithic on the Move. Papers presented at the Sixth International Conference on the Mesolithic in Europe, Stockholm 2000. Eds L. Larsson, H. Kindgren, K. Knutsson, D. Loeffler, A. Åkerlund. Oxford, Oxbow Books, 2003, pp. 414-430.

Rankama T., Kankaanpää J. Eastern arrivals in post-glacial Lappland: The Sujala site 10000 cal BP. Antiquity, 2008, vol. 82, pp. 884-900.

Rankama T., Kankaanpää J. Fast or slow pioneers? A view from Northern Lappland. Lateglacial and Postglacial Pioneers in Northern Europe. British Archaeological Reports, International Series. Vol. 2599. Eds F. Riede, M. Tallavaara. Oxford, Archaeopress, 2014, pp.147-160.

Räihälä O. Suomussalmen Salonsaari kivikautinen leiripaikka Kiantajärven rannalla. Kirjoitelmia arkeologian alalta. Kentältä poimittua 4. Museoviraston arkeologian osaston julkaisuja, vol. 7. Helsinki, Museovirasto, 1997, pp.5-23.

Reimer P. J., Bard E., Bayliss A., Beck J. W., Blackwell P. G., Bronk Ramsey C., Grootes P. M., Guilderson T. P., Haflidason H., Hajdas I., Hatte C., Heaton T. J., Hoffmann D. L., Hogg A. G., Hughen K. A., Kaiser K. F., Kromer B., Manning S. W., Niu M., Reimer R. W., Richards D. A., Scott E. M., Southon J. R., Staff R. A., Turney C.S.M., van der Plicht J. IntCal13 and Marine13 radiocarbon age calibration curves 0-50,000 years cal BP. Radiocarbon, 2013, vol. 55, issue. 4, pp. 1111-1150.

Saarnisto M. The late Weichselian and Flandrian History of the Saimaa Lake Complex. Commentationes physico-mathematicae, 1970, vol.37, pp.3-7.

Schulz H.-P. On the Mesolithic Quarz Industry in Finland. Fenno-Ugri et Slavi. Papers presented by the participants in the Finnish-Soviet Archaeological Symposium 'Studies in the Material Culture of the Peoples of eastern and Northern Europe' 10-16 May 1988 in the National Museum of Finland. (Iskos, vol.9). Ed. by T. Edgren. Helsinki, The Finnish Antiquarian Society, 1988, pp.7-23.

Schulz H.-P. Pioneerit pohjoisessa. Suomen varhaismesoliittinen asutus arkeologisen aineiston valossa. Suomen Museo 1996. Helsinki, 1996. 5-45.

Siiriäinen A. Yli-Iin Kierikin Asbestikeraamisen asuinpaikan kvartsiesineet. Lähdekriittinen tutkimus. Unpublished Master's thesis, University of Helsinki, Helsinki, 1968, 123 p.

Siiriäinen A. Quartz, Chert and Obsidian. A Comparison of Raw Materials in a Late Stone Age Aggregate in Kenya. Finskt Museum 1974. Helsinki, 1977, pp. 15-29.

Siiriäinen A. Problems of the East Fennoscandian Mesolithic. Finskt Museum 1977, Helsinki, 1981, pp. 5-31.

Sulgostowska Z. The Earliest Mesolithic Settlement in North-Eastern Poland. The Earliest Settlement in Scandinavia. (Acta Archaeologica Lundensia Series in 8, No 24). Ed. By L. Larsson. Stockholm, Almqvist \& Wiksell International, 1996, pp. 297-305.

Sulgostowska Z. Final Palaeolithic Masovian Cycle and Mesolithic Kunda Culture Relations. Tanged points cultures in Europe. Read at the international Archaeological Symposium, Lublin, September 13-16, 1993. Eds S. Kozlowski, J.Gurba, L.I.Zalisnyak. Lublin, Maria-Curie Sklodowska University Press, 1999, pp. 85-93.

Sørensen M. Teknologiske traditioner I Maglemosekulturen. En diakron analyse av Maglemosekulturens flækkeindustri. Stenalderstudier. Tidlig Mesolitiske jogere og samlere i Sydskandinavien. Ed. by E. B. V. Århus. Jutland Archaeological Society, 2006, 19-77.

Sørensen M. The Arrival and Development of Pressure Blade Technology in Southern Scandinavia. The Emergence of Pressure Blade Making. From Origin to Modern Experimentation. Ed. by P. M. Desrosiers. New York, 2012, pp. 237-260. 
Sørensen M., Rankama T., Kankaanpää J., Knutsson K., Knutsson H., Melvold S., Eriksen B. V., Glørstad H. The First Eastern Migrations of People and Knowledge into Scandinavia: Evidence from Studies of Mesolithic Technology, 9th-8th Millennium BC. Norwegian Archaeological Review, 2013, vol. 46, iss. 1, pp. 19-56.

Takala H. The Ristola Site in Lahti and the Earliest Postglacial Settlement of South Finland. Jyväskylä, Lahti City Museum, 2003, 205 p.

Tallavaara M., Manninen M. A., Hertell E. \& Rankama T. How flakes shatter. A critical evaluation of Quartz fracture analysis. Journal of Archaeological Science, 2010, vol. 37, 2442-2448.

Tilley C. Conceptual Frameworks for the explanation of Sosio-cultural Change. Pattern of the Past. Eds I. Hodder I, G. Isaac, N. Hammond. Cambridge, Cambridge University Press, 1981, pp.363-386.

Trigger B. G. A History of Archaeological Thought. Cambridge, Cambridge University Press, 1989, 500 p.

Uleberg E. Cultural Landscapes in Stone Age Research. The Mesolithic of Central Scandinavia. (Universitetets Oldsaksamlings Skrifter Ny Rekke nr. 22). Ed by J. Boaz. Oslo, Universitetets Oldsaksamling, 1999, pp. 39-45.

Welinder S. Människor och landskap. (Aun, vol.15). Uppsala, Societas Archaeologica Upsaliensis, 1992. $141 \mathrm{p}$.

Whittaker J. C. Flintknapping. Making and understanding stone tools. Austin, University of Texas Press,1994, $352 \mathrm{p}$

Zhilin M.G. Early Mesolithic communication networks in the East European forest zone. Mesolithic on the Move. Papers presented at the Sixth International Conference on the Mesolithic in Europe, Stockholm 2000. Eds L. Larsson, H. Kindgren, K. Knutsson, D. Loeffler, A. Åkerlund. Oxford, Oxbow Books, 2003, pp. 688-693.

Zhilin M. G. The terminal Paleolithic - Early Mesolithic of the Upper Volga and colonization of the northwest of eastern Europe. Pioneer settlement and colonization Processes in the Barents Region. (Vuollerim papers on Hunter-Gatherer Archaeology, vol. 1). Ed. by H. Knutsson. Vuollerim 6000 År: Vuollerim, 2005, pp. 163-179.

Zhilin M. Early Mesolithic bone arrowheads from the Volga-Oka interfluve, Central Russia. Fennoscandia archaeologica, 2015, vol. XXXII, pp. 35-54.

Статья поступила в редакцию 19 апреля 2018 г. Рекомендована в печать 12 марта 2019 г.

Received: April 19, 2018

Accepted: March 12, 2019 